\title{
A Review of Nutritional and Physiological Factors Affecting Goat Milk Lipid Synthesis and Lipolysis ${ }^{1}$
}

\author{
Y. Chilliard, ${ }^{*}$ A. Ferlay, ${ }^{*}$ J. Rouel, ${ }^{*}$ and G. Lamberet† \\ *Unité de Recherches sur les Herbivores, Equipe Tissu Adipeux et Lipides du Lait, INRA, Theix, \\ 63122 St-Genès-Champanelle, France \\ †Unité de Recherches Laitières et Génétique Appliquée, INRA, 78352 Jouy-en-Josas, France
}

\begin{abstract}
Although the effect of lactation stage is similar, the responses of milk yield and composition (fat and protein contents) to different types of lipid supplements differ greatly between goats and cows. Milk fat content increases with almost all studied fat supplements in goats but not in cows. However, the response of milk fatty acid (FA) composition is similar, at least for major FA, including conjugated linoleic acid (CLA) in goats and cows supplemented with either protected or unprotected lipid supplements. Goat milk CLA content increases sharply after either vegetable oil supplementation or fresh grass feeding, but does not change markedly when goats receive whole untreated oilseeds. Important interactions are observed between the nature of forages and of oil supplements on trans-10 and trans-11 C18:1 and CLA.

Peculiarities of goat milk FA composition and lipolytic system play an important role in the development of either goat flavor (release of branched, medium-chain FA) or rancidity (excessive release of butyric acid). The lipoprotein lipase (LPL) activity, although lower in goat than in cow milk, is more bound to the fat globules and better correlated to spontaneous lipolysis in goat milk. The regulation of spontaneous lipolysis differs widely between goats and cows. Goat milk lipolysis and LPL activity vary considerably and in parallel across goat breeds or genotypes, and are low during early and late lactation, as well as when animals are underfed or receive a diet supplemented with protected or unprotected vegetable oils. This could contribute to decreases in the specific flavor of goat dairy products with diets rich in fat.
\end{abstract}

(Key words: goat milk fat, fatty acids, lipoprotein lipase, lipolysis)

Received May 17, 2002

Accepted October 24, 2002.

Corresponding author: Y. Chilliard; e-mail: Yves.Chilliard@ clermont.inra.fr.

${ }^{1}$ Presented in part at Technical Symposium "Recent advances on goat milk quality, raw material for cheesemaking," 7th International Conference on Goats, 20 May 2000, Poitiers, France.
Abbreviation key: CLA = conjugated linoleic acids, DHA $=$ C22:6 n-3, EPA $=$ C20:5 n-3, FA $=$ fatty acids, $\mathbf{L P L}=$ lipoprotein lipase, $\mathbf{R A}=$ rumenic acid (cis-9, trans-11 CLA).

\section{INTRODUCTION}

Lipid composition is one of the most important components of the technological and nutritional quality of goat milk. Lipids are involved in cheese yield (per kilogram of milk) and firmness, as well as in the color and flavor of caprine dairy products (Delacroix-Buchet and Lamberet, 2000). Besides their quantitative contribution to the amount of dietary energy, the different fatty acids (FA) (short- and medium-chain, saturated, branched, mono- and polyunsaturated, cis and trans, conjugated) are potentially involved as positive or negative predisposing factors for the health of human consumers (Parodi, 1999; Sébédio et al., 1999; Williams, 2000). Furthermore, the pecularities of goat milk lipolytic system (Chilliard, 1982) and medium-chain FA (Ha and Lindsay, 1993) could greatly change the content in free FA, playing a major role in the occurrence of the characteristic goat flavor.

Fat supplementation of diets could improve goat milk composition for greater control of cheese processing and satisfaction of consumer demand. Dietary lipid supplementation may indeed change milk fat FA composition and result in positive or adverse changes in the physical characteristics and the nutritional or dietetic properties of goat dairy products, and/or modify the lipolytic system (Chilliard, 1982) and hence the flavor of these products. Furthermore, the expected positive effects of fat supplementation on goat milk fat content (Chilliard and Bocquier, 1993) could be useful in solving the technological problems of the goat cheese industry, which are linked to a low milk fat content, especially when fat content falls below protein content (the so-called "inversion of percentages syndrome") (Morand-Fehr et al., $2000 b)$. Although fat supplementation in dairy cows and ewes often decreases the milk protein content and the associated coagulation properties, this negative ef- 

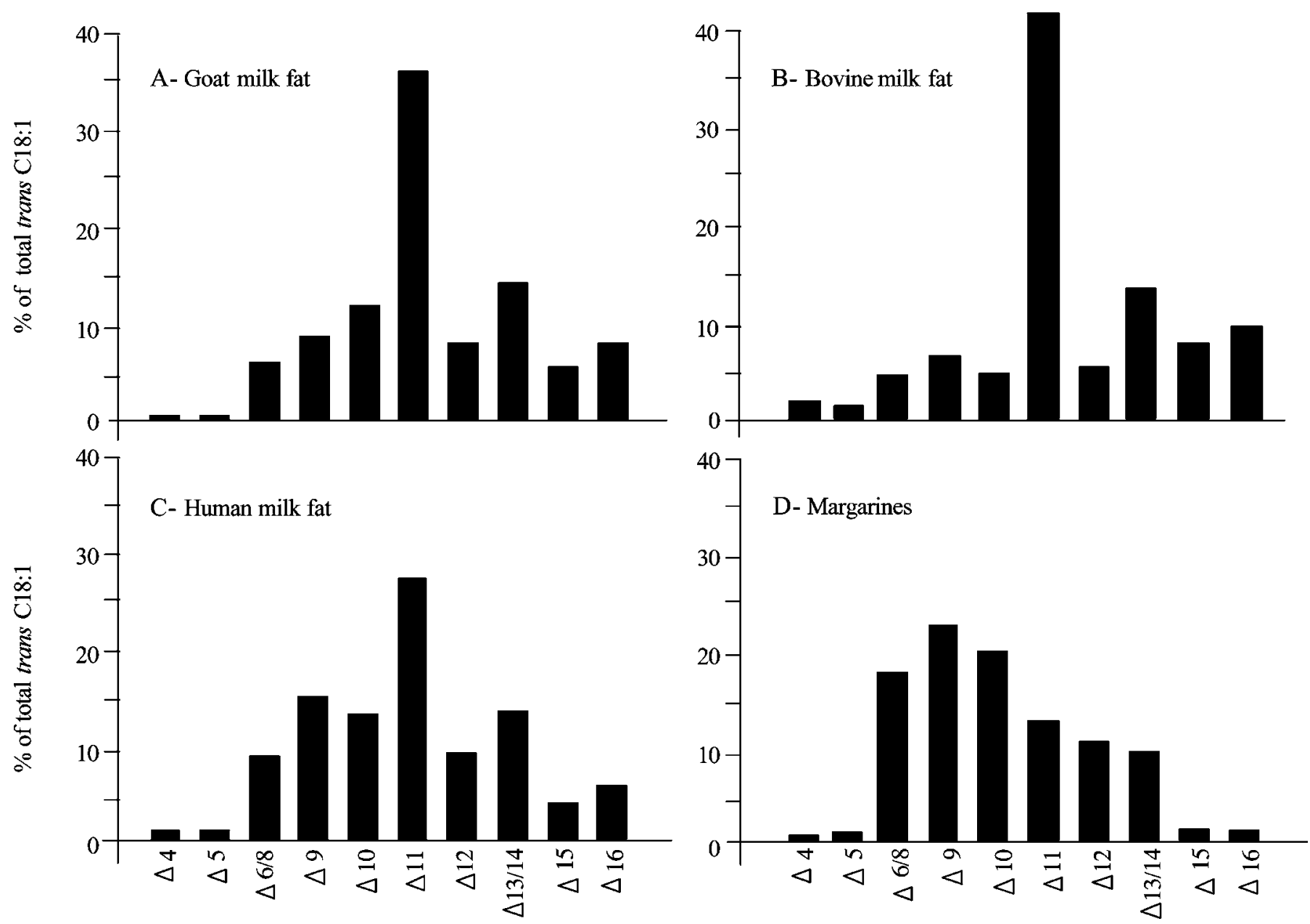

Figure 1. Proportions of isomers of trans C18:1 in different fats. A, from LeDoux et al. (2002); B, C, D, from Precht and Molkentin (1999).

fect could not exist in goats (Chilliard and Bocquier, 1993).

The aim of this paper is to review the main effects of physiological and nutritional factors, and more particularly recent studies on fat supplementation, on goat milk fat and protein contents, fatty acid composition, lipase activity and lipolysis.

\section{MILK FAT SECRETION AND COMPOSITION}

\section{Goat Milk FA Composition}

In comparison with cow milk, goat milk is higher in medium-chain FA (C8, caprylic acid and, more markedly, C10, capric acid). Conversely, cow milk is higher in butyric (C4) and, sometimes, palmitic (C16:0) acids (Glass et al., 1967). Thus, the regulation of mammary cells differs between caprine and bovine species, particularly in the elongation process of FA, which are synthesized de novo by the "fatty acid synthase" complex. A detailed comparison of the mechanisms between these two species would contribute to a better knowledge of the regulation of milk fat synthesis in ruminants (Knudsen and Grunnet, 1982), which is less well known than in rodent species (Barber et al., 1997).

Milk unsaturated FA may contain one or several trans double bonds. About 5 to $15 \%$ of total C18:1 are of trans configuration in goat (Bickerstaffe et al., 1972; Calderon et al., 1984; Alonso et al., 1999), cow (Storry and Rook, 1965; Selner and Schultz, 1980) and human species (Jensen, 1989; Guesnet et al., 1993). However, the proportion of different trans isomers varies between species: the main FA (35 to 40\%) is trans-vaccenic acid (C18:1, n-7 or $\Delta 11$ ) in goat and cow milk (Bicherstaffe et al., 1972; Alonso et al., 1999; LeDoux et al., 2002; Figure 1A and B), whereas human milk fat trans C18:1 contains larger percentages of $\mathrm{FA}$ with the double bond located on carbons 6 to 14 (Figure 1C). The profile of human milk fat is probably related to the consumption 


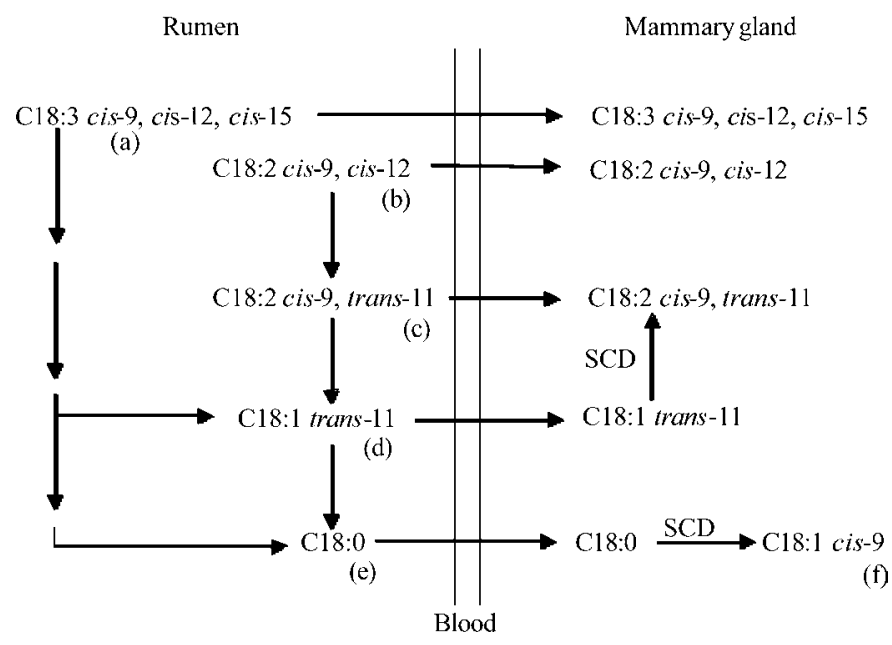

Figure 2. Main pathways of milk trans fatty acids and conjugated linoleic acid synthesis (from Griinari and Bauman, 1999). (a) linolenic acid, (b) linoleic acid, (c) rumenic acid, (d) trans-vaccenic acid, (e) stearic acid, (f) oleic acid; SCD, stearoyl-CoA (delta-9) desaturase.

of a mixture of ruminant milk fat and of margarines, the latter being richer in $\Delta 6$ to $\Delta 14$ - trans C18:1, especially $\Delta 6$ to $\Delta 10$ (Figure $1 \mathrm{D}$ ). Quantitatively, the trans $\mathrm{C} 16: 1$ isomers represent less than $0.2 \%$ of total $\mathrm{FA}$, or 5\% of all trans $\mathrm{C} 16: 1$ and C18:1 isomers in ruminant milk fat. The distribution patterns of cis and trans C16:1 isomers are very similar for goat, cow, and ewe cheese fat (Destaillats et al., 2000).

The trans FA of margarines originate from industrial hydrogenation of polyunsaturated FA from vegetable oils, whereas ruminant trans FA originate from ruminal hydrogenation of polyunsaturated FA of forages and concentrates (Figure 2). Conjugated linoleic acid (CLA) is a precursor of trans-vaccenic acid in the rumen and a product of the delta-9 desaturation of this FA in the mammary gland (Figure 2). The major isomer (more than $90 \%$ ) of bovine milk CLA (cis-9, trans-11 C18:2, or rumenic acid, RA) originates mainly from the latter pathway (Griinari and Bauman, 1999). It is interesting to emphasize that milk fat from monogastric farm animals such as mare or sow (that do not consume ruminant milk fat or margarines) is almost devoid of transvaccenic acid and RA, whereas human milk fat is of an intermediate composition (Jahreis et al., 1999). In that study, the trans-vaccenic and RA contents of goat milk fat were lower than those of milk fat from cow or ewe receiving similar diets. However, the mean milk RA values from three other goat studies were in the range 0.4 to $0.9 \%$ of total FA (Alonso et al., 1999; Gulati et al., 2000; Chilliard et al., 2002), i.e., similar to observations in dairy cows receiving diets without added lipids (Griinari and Bauman, 1999; Chilliard et al., 2000).

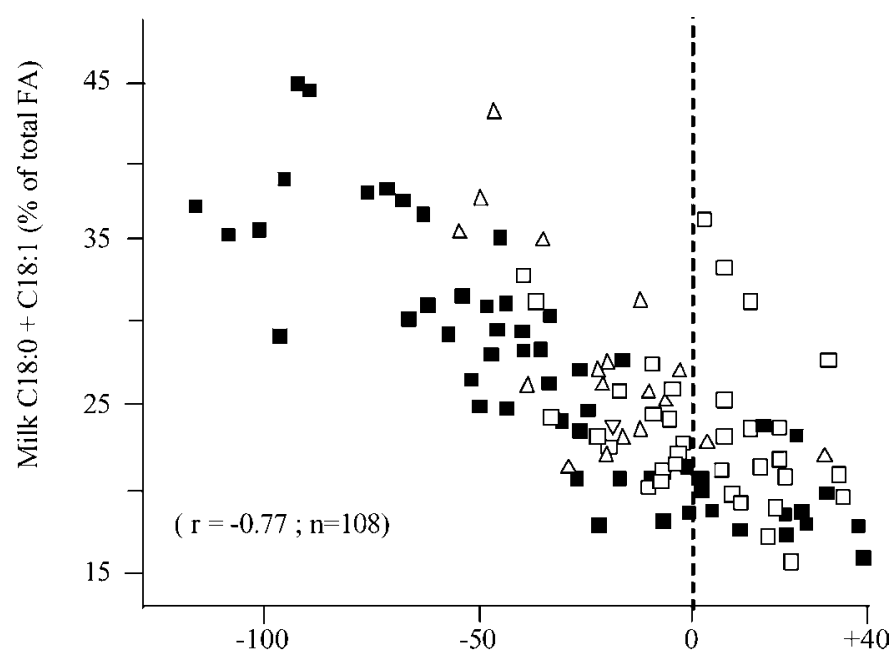

Energy balance ( $\mathrm{kcal} \mathrm{NE} / \mathrm{d} / \mathrm{kg}^{0,75}$ )

Figure 3. Goat energy balance and milk long-chain fatty acids (FA) (from Chilliard, 1985, and Chilliard et al., 1987). Milk fat content and FA composition were studied in 108 milk samples from 19 Alpine goats, receiving alfalfa hay and concentrate, between wk 1 and 18 of lactation; = lactation after normal parturition (10 goats); $\Delta=$ lactation after abortion (4 goats); $\square=$ hormonally induced lactation in nonpregnant goats (5 goats). The following correlations were observed: milk C18:0 + C18:1 (\%) versus energy balance, $\mathrm{r}=-0.77$; milk fat content versus energy balance, $\mathrm{r}=-0.58$; milk fat content versus plasma NEFA content, $\mathrm{r}=+0.46$; milk fat content versus milk C18:1 $(\%), r=+0.47$.

\section{Effects of Changes in Lactation Stage and Energy Balance on Milk Fat Secretion and Composition}

Milk fat content is high after parturition and then decreases during the major part of lactation in the goat (Chilliard et al., 1986; Sauvant et al., 1991) as in the cow (Jarrige et al., 1978). This is related to at least two phenomena: a dilution effect due to the increase in milk volume until the lactation peak, and a decrease in fat mobilization that decreases the availability of plasma NEFA, especially C18:0 and C18:1, for mammary lipid synthesis. Highly significant correlations were found between milk fat content and either energy balance, plasma NEFA content or milk fat C18:1 percentage, respectively (see Figure 3).

The nutritional status of lactating animals can be estimated by their energy (or protein, mineral, etc.) balance, i.e., by the difference between ingested nutrients and requested nutrients for body maintenance and for milk secretion. This balance is highly variable, according to animal milk genetic potential and lactation stage, as well as to composition and nutrient density of the diet. When energy balance is negative, animals mobilize lipids stored in adipose tissues, mainly in the form of NEFA. As ruminant adipose tissues are very 


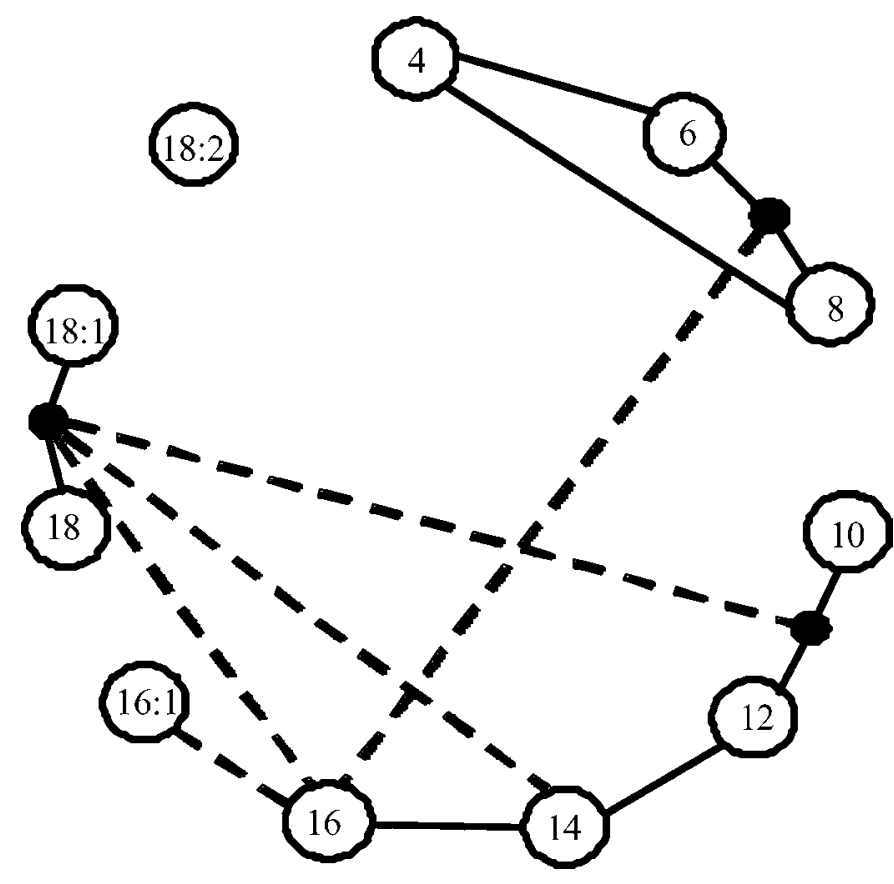

Figure 4. Major correlations between fatty acids (\% of total FA) in goat milk (from Chilliard, 1985, and Chilliard et al., 1987: 108 milk samples from 19 goats, see Figure 1). Only r-values $>0.71$ (continuous lines) or $<-0.71$ (dotted lines), i.e., $\mathrm{r}^{2}>0.50$, have been indicated.

rich in palmitic, stearic, and oleic acids (see Bas et al., 1987, for goat tissues), this explains that $59 \%$ of the variability of milk C18:0 + C18:1 content (which represent from 15 to $45 \%$ of total milk FA) was linked to changes in energy balance, in goats with different milk yields, and receiving classic hay plus concentrate diets (without fat supplementation) during the first 4 mo of lactation (Figure 3). Correlations between the percentages of individual FA in these milks show three main families: C18-FA, C10 to C16-FA (negatively correlated to the C18-FA family), and C4 to C8-FA (not highly correlated to the two other families, with the exception of the negative correlation to C16:0) (Sauvant et al., 1973, and Figure 4). These correlations result mainly from the negative effect of long-chain (C18) FA that are mobilized from adipose tissue on de novo synthesis of medium-chain FA (C10 to C16; Barber et al., 1997), and from the fact that short-chain FA arise in part from metabolic pathways that do not involve malonyl-CoA and acetyl-CoA carboxylase activity (Bauman and Davis, 1974; Palmquist and Jenkins, 1980).

\section{Effects of Lipid Supplementation on Milk Fat Secretion}

Dietary factor (forage-to-concentrate ratio, type of forages, etc.) effects on goat milk composition have been reviewed by Morand-Fehr et al. (2000a). Dietary lipid supplementation is a means for increasing both energy intake and efficiency in early lactation-high yielding cows, thereby increasing milk yield, but it did not limit the mobilization of body lipids (Chilliard, 1993). Effects of lipid supplementation on goat milk secretion have been reviewed by Morand-Fehr et al. (1982) and Polidori et al. (1991). Feeding diets very low in lipids decreased goat milk yield and fat content, and this was reversed by lipid supplementation (Delage and Fehr, 1967; Morand-Fehr et al., 1984a, Table 1).

In four early-lactation trials (Table 1), lipid supplementation tended to increase milk yield $(+0.1$ to +0.4 $\mathrm{kg} / \mathrm{d}$ or more when the control diet was very low in fat) and fat content $(+2$ to $+7 \mathrm{~g} / \mathrm{kg})$. Effects on protein content were highly variable. The calculated energy balance increased or decreased according to respective effects on intake of DM and energy, and milk fat secretion. In three other early-lactation trials, milk yield and protein content remained unchanged, and fat content increased, with either protected sunflower seeds (15\% of concentrate; Morand-Fehr et al., 1984a), extruded soybeans (160 g/d; Morand-Fehr et al., 1984b) or calcium soaps of palm oil (100 g/d; Martin et al., 1999). There were no clear trends concerning effects of fat supplementation on goat BW changes or body fat mobilization during early lactation. Results from early-lactation experiments are limited by their lack of precision, linked to possible differences in milk potential of animals and limited use of covariates, when lipid supplementation begins before or immediately after parturition.

Contrary to what was observed in dairy cows (Chilliard et al., 2001), feeding fat supplements to mid- or late-lactation goats did not increase milk yield, whereas milk fat content always increased sharply $(+5.7 \mathrm{~g} / \mathrm{kg}$ in 23 supplemented groups in Table 2). The ranges of observed responses were similar with different types of fat supplements: saturated free FA, calcium salts or triglycerides; animal fat; vegetable oils (C18:1-, C18:2-, or C18:3-rich oils; free oils, encapsulated oils); oilseed (whole, crushed, extruded, or formaldehyde-treated oil seeds) (Table 2, and Schmidely and Sauvant, 2001). Remarkably, goat milk fat content did not decrease even when vegetable oils (rich in polyunsaturated FA) were added to a low-forage diet (e.g., footnote 8 in Table 2 ), contrary to what was very clearly observed in dairy cows (Bauman and Griinari, 2001). As previously observed for early-lactation goats, response of milk protein content was highly variable in midlactation goats (Table 2). Body weight gain was either higher (Baldi et al., 1992), lower (Gelaye and Amoah, 1988), or unchanged (footnote 8 in Table 2 ) in fat supplemented vs. control goats. 
Table 1. Effects of fat supplementation on dairy performance ${ }^{1}$ in early-lactation goats.

\begin{tabular}{|c|c|c|c|c|c|c|c|}
\hline $\begin{array}{l}\text { Lipid } \\
\text { sources } \\
\text { (\% of concentrate) }\end{array}$ & $\begin{array}{l}\text { Lactation } \\
\text { stage } \\
\text { (wk) }\end{array}$ & $\begin{array}{l}\mathrm{DMI} \\
(\mathrm{kg} / \mathrm{d})\end{array}$ & $\begin{array}{l}\text { Milk } \\
\text { yield } \\
(\mathrm{kg} / \mathrm{d})\end{array}$ & $\begin{array}{l}\text { Fat } \\
\text { content } \\
\text { (g/kg) }\end{array}$ & $\begin{array}{l}\text { Protein } \\
\text { content } \\
(\mathrm{g} / \mathrm{kg})\end{array}$ & $\begin{array}{l}\text { Calculated } \mathrm{EB}^{2} \\
(\mathrm{kcal} / \mathrm{d})\end{array}$ & References \\
\hline Fat prills, ${ }^{3} 10 \%$ & \multirow[t]{2}{*}{$2-8$} & -0.05 & +0.38 & +4.0 & +2.1 & +357 & \multirow[t]{2}{*}{ Morand-Fehr et al., 1987} \\
\hline Tallow, ${ }^{4} 5 \%$ & & -0.10 & +0.06 & +4.8 & +3.3 & +193 & \\
\hline Tallow, $5 \%^{5}$ & \multirow{2}{*}{$1-8$} & +0.19 & +1.20 & +2.4 & -1.3 & & \multirow{2}{*}{ Morand-Fehr et al., 1984a } \\
\hline Soybean oil, ${ }^{6} 5 \%^{5}$ & & +0.36 & +1.00 & +3.1 & -1.0 & & \\
\hline Alifet, $12 \%$ & $\begin{array}{l}1-8 \\
3-11\end{array}$ & +0.10 & -0.16 & +5.8 & +1.0 & -411 & Brown-Crowder et al., 2001 \\
\hline
\end{tabular}

${ }^{1}$ Difference between fat supplemented and control groups.

${ }^{2} \mathrm{~EB}=$ energy balance, calculated from milk yield and DMI.

${ }^{3}$ Fat prills contains $45 \% \mathrm{C} 16: 0+48 \% \mathrm{C} 18: 0+8 \% \mathrm{C} 18: 1$.

${ }^{4}$ Tallow contains ca. $25 \%$ C16:0 + 20\% C18:0 + 40\% C18:1.

${ }^{5}$ The control diet (hay + beet pulp) was low in fat.

${ }^{6}$ Soybean oil contains 12\% C16:0 + 20\% C18:1 + 50\% C18:2.

${ }^{7} \mathrm{An}$ emulsion of $40 \%$ animal tallow with $60 \%$ soybean meal protein, treated with formaldehyde and spray dried.

${ }^{8}$ Partially hydrogenated tallow plus $7 \%$ starch (Alifet, Cincinatti, OH). Alifet contains 25\% C16:0 + 35\% C18:0 + 13\% trans C18:1 + 15\% cis C18:1 (Palmquist, 1991).

${ }^{9}$ Diet containing $50 \%$ alfalfa hay.

The response of dairy goats to fish oil supplements is not well known but differs from the responses to other fat supplements. Feeding unprotected fish oil to goats sharply decreased DMI and milk yield without changing milk fat content (Kitessa et al., 2001). This differs markedly from cow responses, where milk yield increased (despite a significant decrease in dry matter intake) and milk fat content decreased sharply (Chilliard and Doreau, 1997). Feeding partially protected fish oil ( $20 \mathrm{~g} / \mathrm{d}$ of EPA + DHA) to goats did not change intake, milk yield, or milk fat content (Kitessa et al., 2001). This contradicts the results of Léger et al. (1994), showing that a duodenal infusion of EPA + DHA $(4 \mathrm{~g} / \mathrm{d})$ decreased goat milk fat content, as observed in cows (Chilliard et al. 2000, 2001).

The response of milk fat secretion to fat supplementation could be lower during midlactation than during early lactation (Figure 5). This could be related to the fact that goat adipose tissue anabolic enzymes involved in de novo lipogenesis, and lipoprotein lipase (the enzyme involved in the uptake of blood lipoproteins carrying dietary FA absorbed from the intestine), are more active after the lactation peak than before it (Chilliard et al., 1977, 1979a), because they are positively related to energy balance (Chilliard et al., 1987). Body lipid mobilization dominates during early lactation, and this would favor the partitioning of dietary FA towards the mammary gland (Chilliard, 1993). It results from these events that a greater part of the exogenous FA are taken up by the adipose tissue after the lactation peak (Chilliard et al., 1991). However, contrary to milk fat secretion, the highest milk fat content responses were observed in late-lactating or low-yielding goats (Table 2 ), probably because the dietary FA were less diluted in the milk of these animals.

Results available in dairy cattle (Chilliard et al., 2001), goat (Chilliard and Bocquier, 1993, and present review), and sheep (Chiofalo et al., 1993; Caja and Bocquier, 2000; Nudda et al., 2002) show that responses to fat supplementation differ considerably according to the species:

- milk yield increases in midlactation dairy cows, but not in goats and ewes;

- milk fat content (and fat secretion) sharply increases in dairy ewes and goats, but not always in dairy cows in which it could often either decrease or not change;

- milk protein content decreases in dairy cows and ewes, but not in goats. Milk protein secretion decreases in milking ewes, but does not change in dairy cows and goats.

The reasons for these differences in dairy performance response to fat supplementation between ruminant species are not easy to identify, as fewer trials and less information are available for ewes and goats than for dairy cows. The differences may be linked to complex digestive and metabolic interactions (as observed in dairy cows) between the basal diet (nature and proportion of forages and concentrates), fat supplementation (nature and technological treatment, dose and/or duration) and animal characteristics (species, breed, lactation stage, milk potential, etc.; see reviews from Chilliard et al., 2000; Bauman and Griinari, 2001). It has been suggested that the rate of passage of digesta 
Table 2. Effects of fat supplementation on dairy performance ${ }^{1}$ in mid- or late-lactation goats.

\begin{tabular}{|c|c|c|c|c|}
\hline $\begin{array}{l}\text { Lipid sources } \\
\text { (\% of concentrate) }\end{array}$ & $\begin{array}{l}\text { Milk yield } \\
(\mathrm{kg} / \mathrm{d})\end{array}$ & $\begin{array}{l}\text { Fat content } \\
(\mathrm{g} / \mathrm{kg})\end{array}$ & $\begin{array}{l}\text { Protein content } \\
(\mathrm{g} / \mathrm{kg})\end{array}$ & References \\
\hline Palmitic acid, $14 \%$ & -0.06 & +11.4 & & Astrup et al., 1985 \\
\hline Stearic acid, $14 \%$ & +0.10 & +6.5 & & Astrup et al., 1985 \\
\hline Animal $\mathrm{fat}^{2}$ & +0.38 & +2.0 & -1.0 & Gelaye and Ámoah, 1988 \\
\hline Animal fat ${ }^{2}$ & -0.29 & +7.0 & +1.0 & $\mathrm{Lu}, 1993$ \\
\hline Animal fat, $4 \%$ & -0.09 & +3.7 & +1.4 & Daccord, 1987 \\
\hline Calcium salts, $15 \%^{3}$ & -0.02 & $+14.2^{4}$ & +1.5 & De Maria Ghionna et al., 1987 \\
\hline Calcium salts & +0.10 & +3.7 & -0.1 & Teh et al., 1994 \\
\hline Calcium salts ${ }^{5}$ & +0.21 & +5.2 & +0.3 & Rousselot et al., 1995 \\
\hline Calcium salts, $6 \%{ }^{6}$ & +0.10 & +3.0 & 0.0 & Baldi et al., 1992 \\
\hline Canola oil, $4 \%$ & +0.19 & +9.2 & -0.3 & Mir et al., 1999 \\
\hline Treated linseeds, $23 \%^{7}$ & -0.20 & +6.3 & +1.4 & Ferlay et al. ${ }^{7}$ \\
\hline Linseeds, $14 \%^{8}$ & +0.27 & +5.5 & +2.5 & Rouel et al. ${ }^{8}$ \\
\hline Linseed oil, $5 \%^{8}$ & +0.30 & +4.2 & +2.4 & Rouel et al. ${ }^{8}$ \\
\hline Sunflower seeds, $9 \%^{8}$ & +0.42 & +6.3 & +2.1 & Rouel et al. ${ }^{8}$ \\
\hline Sunflower oil (SO), $5 \% 8$ & +0.42 & +4.9 & +1.3 & Rouel et al. ${ }^{8}$ \\
\hline High-oleic SO, $8 \%^{7}$ & -0.10 & +7.2 & +0.3 & Ferlay et al. ${ }^{7}$ \\
\hline Lupine, $51 \%^{8}$ & +0.23 & +2.8 & +1.9 & Rouel et al. ${ }^{8}$ \\
\hline Soybean, $26 \%^{8}$ & +0.49 & +3.9 & +1.4 & Rouel et al. ${ }^{8}$ \\
\hline Soybean, $49 \%^{9}$ & -0.14 & $+9.3^{4}$ & +0.3 & Bernard et al. ${ }^{9}$ \\
\hline Extruded soybean, $20 \%$ & -0.69 & +4.5 & +1.9 & Daccord, 1987 \\
\hline Cottonseeds, $18 \%$ & -0.02 & +4.4 & & Bartocci et al., 1988 \\
\hline Protected oil, $7 \% 10$ & +0.08 & +2.9 & -0.8 & Lanzani et al., 1985 \\
\hline Olive cake silage ${ }^{11}$ & -0.05 & +3.1 & -0.5 & Hadjipanayiotou, 1999 \\
\hline Mean response ( \pm sd) & $+0.07( \pm 0.27)$ & $+5.7^{\mathrm{a}}( \pm 3.0)$ & $+0.9( \pm 1.1)$ & \\
\hline
\end{tabular}

\footnotetext{
${ }^{\text {a }}$ Significant response $(P<0.01)$.

${ }^{1}$ Difference between fat supplemented and control groups.

${ }^{2} 5 \%$ of the ration.

${ }^{3}$ Calcium salts of palm oil, fed to low-yielding goats $(1.6 \mathrm{~kg} \mathrm{milk} / \mathrm{d})$.

${ }^{4}$ High response in late-lactation or low-yielding goats.

${ }^{5}$ Calcium salts of palm oil, $3-4 \%$ of the ration.

${ }^{6}$ Calcium salts of sunflower (50\%), tallow and lard.

${ }^{7}$ Diets with $3.6 \%$ added fat from formaldehyde-treated crushed linseeds or high-oleic sunflower oil; five goats per group (A. Ferlay, J. Rouel, L. Bernard and Y. Chilliard, unpublished).

${ }^{8}$ Low-forage (30\% of total DM) diets with $3.4 \%$ added fat, 12 goats per group (J. Rouel, E. Bruneteau and Y. Chilliard, unpublished).

${ }^{9}$ Diets with $3.8 \%$ added fat, four late-lactation $(280 \mathrm{~d})$ goats per group (L. Bernard, J. Rouel and Y. Chilliard, unpublished).

${ }^{10}$ Protected oil was $25 \%$ soybean oil and $75 \%$ maize meal treated with formaldehyde. The supplemented group differed also from control group by receiving 30\% of the concentrate DM as liquid feed (molasses, animal protein, etc.).

${ }^{11}$ Diet containing $16 \% \mathrm{DM}$ as olive cake silage, corresponding to $1.4 \%$ added fat.
}

is higher in goats than cows (Hart, 2000). This could decrease in goats the effects of dietary FA on the yield of some ruminal factors that reduce mammary lipogenesis in cows.

Effects on mammary metabolism of the balance and availability of glucogenic, lipogenic, and aminogenic nutrients (including related endocrine changes) are not completely understood, and may vary between species, thus changing their relative responses in lactose, fat, and protein secretions. Furthermore, the caprine $\alpha$-s 1 casein locus is remarkable for its high level of polymorphism and for the fact that important differences exist in milk protein content and, in some cases, in fat content between alleles or groups of alleles (Grosclaude et al., 1994; Tables 3 and 4). It is not known whether the response to dietary fat supplementation would be different between these genotypes.

Goat milk production is largely used for transformation into cheese. Fat supplementation changes goat milk composition in ways that allow a better control of cheese processing. Indeed, one problem encountered with fat supplementation in dairy cows and ewes is that the milk protein content is most of times reduced, thus altering coagulation properties. However, this negative effect does not exist in goats (Table 2). Furthermore, the clear positive effects of almost all types of fat supplementation on milk fat content could be useful to solve the technological problems of the goat cheese industry which are linked to the so-called "inversion of percentages syndrome" during the spring and summer 


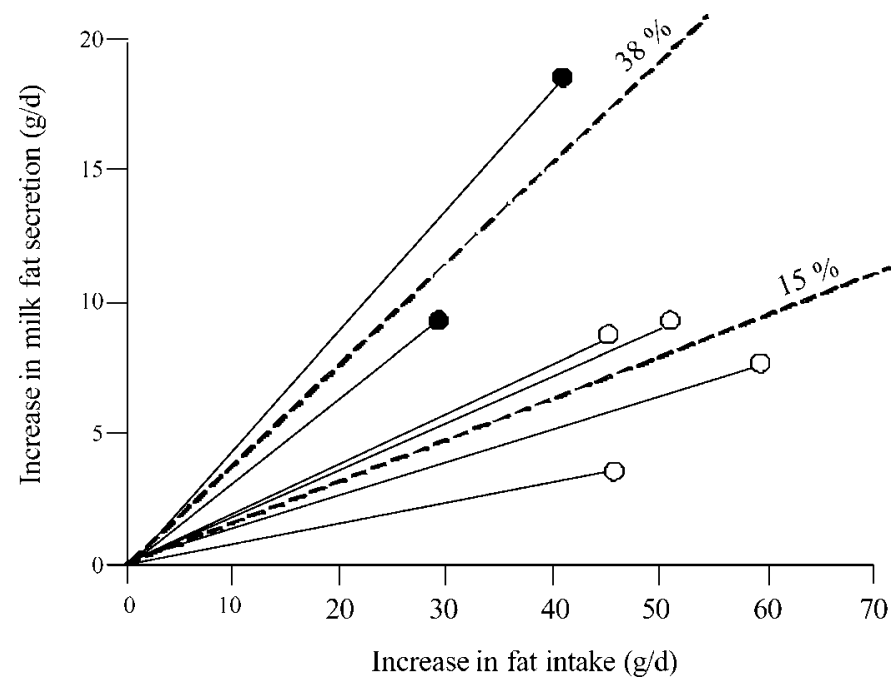

Figure 5. Response of milk fat secretion to fat intake in the goat, according to lactation stage: early $(\bullet)$, or mid-lactation $(\bigcirc)$ (from Sauvant et al., 1983).

period (Bocquier et al., 2000; Morand-Fehr et al., $2000 \mathrm{~b})$. This effect could be related to the combined effects of lactation stage (see above and Table 4), day length (dilution effect, due to stimulation of milk yield; Linzell, 1973; Chilliard and Bocquier, 2000), and/or nutritional factors. Indeed, high-concentrate diets used in high-yielding goats (Sauvant and Morand-Fehr, 2000) are more frequently subject to this syndrome than corn silage-based diets (Rouel et al., 2000). The inversion syndrome occurred whatever the $\alpha$-s1 casein genotype of the goats (Table 4). Changes in milk fat FA composition are another very important consequence of dietary lipid supplementation that may result in positive or adverse changes in the flavor, the physical characteristics and the nutritional or dietetic properties of dairy products.

\section{Effects of Lipid Supplementation on Milk FA Composition}

Palmitic or stearic acid. Feeding of palmitic acid increased goat milk C16:0 percentage considerably (and

Table 3. Effects of AA and FF $\alpha$ s1-casein variants on Alpine goat milk composition, lipolysis creaming ability and cheese characteristics. ${ }^{1}$

\begin{tabular}{lcc}
\hline$\alpha$ s1-Casein variant & AA & FF \\
\hline Casein content $(\mathrm{g} / \mathrm{kg})$ & 28 & 24 \\
Fat content $(\mathrm{g} / \mathrm{kg})$ & 35 & 32 \\
Cream fat content $(\mathrm{g} / \mathrm{L})$ & 350 & 180 \\
Lipase activity $(\mu \mathrm{mol} / \mathrm{h} / \mathrm{ml})$ & 2.5 & 4.3 \\
FFA $(\mathrm{mmol} / 100 \mathrm{~g}$ fat) & 0.32 & 0.47 \\
Cheese goat flavor & 1.3 & 1.9 \\
Cheese firmness & 91 & 69 \\
\hline
\end{tabular}

${ }^{1}$ From Delacroix-Buchet et al. (1996 and personal communication).
C16:1 to a lesser extent) at the expense of C10:0 to C14:0 and of C18:1. When stearic acid was fed instead, milk $\mathrm{C} 18: 0$ and $\mathrm{C} 18: 1$ percentages increased considerably, at the expense of C10:0 to C16:1 (Table 5). These results illustrate the important role of mammary delta9 desaturase in regulating the monounsaturated:saturated FA ratio, especially for C18 FA.

Calcium salts of palm oil. In three trials, feeding calcium salts of palm oil (rich in palmitic and oleic acids) to lactating goats increased the percentage of C18:1 and/or C16:0 in milk fat (Table 6). Another goat trial also reported an increase in milk C16:0 percentage (Sleiman et al., 1998). These results are comparable to those observed in dairy cows, showing increases in both palmitic acid and C18:1 (Table 6), although the responses were more marked in goats.

Encapsulated oils. When vegetable oils or oilseeds are fed to ruminants, their polyunsaturated FA are largely hydrogenated in the rumen (Figure 2), unless these lipid supplements are efficiently protected by encapsulation in a formaldehyde-treated protein coat (McDonald and Scott, 1977). This is illustrated by data in Table 5 showing that feeding protected canola seeds to goats increased milk C18:1, C18:2, and C18:3 proportionally to the respective percentages of these FA in canola oil. On the other hand, feeding unprotected oil increased mainly C18:0 and C18:1, the latter increase probably being due, to a large extent, to unidentified trans isomers of C18:1 (cf. Griinari and Bauman, 1999; Chilliard et al., 2000, 2001, for data in cows). This illustrates that both total and partial hydrogenation of unsaturated FA take place in the rumen (Figure 2).

Feeding protected soybean oil sharply increased milk C18:2 percentage (Table 5). The increase in C18:0 (and probably part of the C18:1) could be because some soybean oil escaped protection and was hydrogenated to C18:0 and trans-C18:1. In this trial, the increase in milk C18-FA was compensated for by a sharp decrease in the C16:0 percentage, although there was a trend for increasing short- and medium-chain FA percentages.

The effect of feeding protected cottonseeds differed from that of other vegetable oils, resulting in a large increase in the milk C18:2 percentage and in the C18:0 to $\mathrm{C} 18: 1$ ratio, despite the fact that this oil is poor in C18:0 and contains only 16\% of C18:1 (Table 5). This response is related to the fact that cottonseeds are rich in cyclopropenoic FA, which are strong inhibitors of mammary delta-9 desaturase activity. With unprotected cottonseeds, the increase in milk C18:2 did not occur, whereas the increase in milk C18:1 (Table 5) was probably due in part to unidentified trans isomers of C18:1 arising from C18:2 hydrogenation in the rumen.

Responses were different when linseeds were added to the diet. Milk C18:3 (n-3) percentage was signifi- 
Table 4. Effects of casein $\alpha$-s1 genotype and lactation stage on Alpine goat milk composition and lipolysis. ${ }^{1}$

\begin{tabular}{lccccc}
\hline Casein $\alpha$-s1 genotype & \multicolumn{3}{c}{ High $^{2}$} & & \multicolumn{2}{c}{ Low $^{3}$} \\
\cline { 2 - 3 } \cline { 5 - 6 } Lactation stage (mo) & 2 & 6 & & 2 & 6 \\
\hline Milk yield (kg/d) & 3.3 & 2.9 & 3.5 & 3.2 \\
Protein content (g/kg) & 32.2 & 32.3 & & $28.1^{\mathrm{b}}$ & $26.9^{\mathrm{b}}$ \\
Fat content (g/kg) & 36.4 & $28.7^{\mathrm{a}}$ & & $29.5^{\mathrm{b}}$ & $22.6^{\mathrm{a}, \mathrm{b}}$ \\
Lipolysis (mmol FFA/100 g fat) & 0.78 & 1.56 & & 0.64 & $2.30^{\mathrm{a}}$ \\
\hline
\end{tabular}

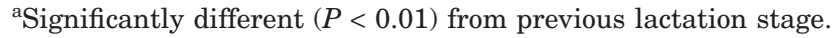

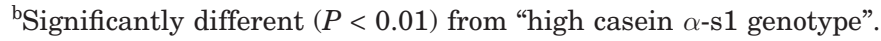

${ }^{1}$ Y. Chilliard, J. Rouel and C. Leroux (unpublished results).

${ }^{2}$ Ten AA goats.

${ }^{3}$ Ten goats (6EF, $2 \mathrm{EO}$ and $\left.2 \mathrm{FF}\right)$.

cantly increased by 159 or $320 \%$ when goats received a diet with $4 \%$ added fat from either crushed linseeds or formaldehyde-treated crushed linseeds, respectively (Y. Chilliard, P. Capitan, J. Rouel, A. Ferlay, unpublished results). These results show that $\mathrm{C} 18: 3$ was partially protected in crushed linseeds, and that formaldehyde treatment approximately doubled $(P<0.01)$ its degree of protection.

Unprotected oils or seeds. The response to feeding different kinds of unprotected lipid supplements consisted mainly of an increase in the percentages of milk C18:0 and C18:1, at the expense of mainly C8 to C14 (and C16:0 in most trials; Astrup et al., 1985; De Maria Ghionna et al., 1987; Bartocci et al., 1988; Baldi et al., 1992; Mir et al., 1999; Schmidely and Sauvant, 2001; Tables 7 and 8). This was probably due to the ruminal hydrogenation of polyunsaturated FA into C18:0 and trans-C18:1, which are inhibitors of the de novo FA synthesis, mainly $\mathrm{C} 8$ to $\mathrm{C} 16$. The final response of milk C16:0 percentage depended on the level of dietary intake, that is, the C16:0 percentage in the lipid supplement which was studied. The decreases of C12:0 to C16:0 resulted in a sharp decrease in the atherogenicity index of the milk fat (Tables 7 and 8). The responses to fat supplementation of $\mathrm{C} 4$ to $\mathrm{C} 8$ were less marked, or even opposite to those of $\mathrm{C} 10$ to $\mathrm{C} 14$ (Tables 5, 7, and 8), and this peculiarity is probably related to their origin from nonmalonyl CoA pathways (see above).

The responses to unprotected fish oil supplementation (3\% of diet DM, Kitessa et al., 2001) consisted of an increase in milk fat trans-C18:1 percentage, a decrease in C18:0, small increases in C20:5 and C22:6, the appearance of 10-hydroxystearic acid, and a very sharp (+33\%) increase in oleic acid, probably due to body fat mobilization since DMI decreased by $50 \%$. The transfer rates to milk of $\mathrm{C} 20: 5$ and $\mathrm{C} 22: 6$ (about 4 to

Table 5. Effect of different lipid supplements ${ }^{1}$ on goat milk fatty acid composition.

\begin{tabular}{|c|c|c|c|c|c|c|c|}
\hline Supplement & \multicolumn{2}{|c|}{ Saturated $\mathrm{FA}^{2}$} & \multicolumn{2}{|c|}{ Canola seeds ${ }^{3}$} & $\frac{\text { Soybean oil }}{\text { Protected }}$ & \multicolumn{2}{|c|}{ Cotton seeds ${ }^{5}$} \\
\hline \multicolumn{8}{|c|}{ Fatty acids (w\% of total FA) } \\
\hline $\mathrm{C} 10: 0$ to $\mathrm{C} 14: 0$ & -4.4 & -4.2 & -0.6 & -2.0 & +1.9 & -2.1 & -6.0 \\
\hline C16:0 & +6.4 & -6.2 & -8.2 & -4.1 & -8.7 & -2.0 & -4.3 \\
\hline C16:1 & +2.4 & -2.0 & nd & nd & nd & nd & nd \\
\hline C18:3 & +0.3 & -0.6 & +3.1 & +0.5 & nd & 0.0 & +0.2 \\
\hline
\end{tabular}

${ }^{1}$ Effects expressed as the difference between fat supplemented and non-supplemented control groups. nd = not determined.

${ }^{2} \mathrm{C} 16: 0$ or C18:0 (14\% of the concentrate); from Astrup et al. (1985).

${ }^{3} 110$ g oil/d (55\% C18:1 + 25\% C18:2 + 11\% C18:3); from Gulati et al. (1997).

${ }^{4}$ Soybean oil $(12 \% \mathrm{C} 16: 0+20 \% \mathrm{C} 18: 1+50 \% \mathrm{C} 18: 2)$ at $1.8 \%$ of concentrate, in formadelhyde treated maize meal; from Lanzani et al. (1985).

${ }^{5}$ Cottonseed oil contains $22 \% \mathrm{C} 16: 0+16 \% \mathrm{C} 18: 1+57 \% \mathrm{C} 18: 2$.

${ }^{6} 110 \mathrm{~g}$ lipids/d; from Gulati et al. (1997).

${ }^{7} 34 \mathrm{~g}$ lipids/d; from Bartocci et al. (1988).

${ }^{8} \mathrm{c} / \mathrm{t}=$ cis $/$ trans . 
Table 6. Effects of feeding calcium salts of palm oil on milk FA (\%).

\begin{tabular}{lclllr}
\hline & Intake $^{1}$ & C16:0 & C18:0 & C18:1 & C18:2 \\
\hline Goat $^{2}$ & 92 & +0.4 & +0.3 & +6.4 & +0.5 \\
Goat $^{3}$ & 100 & +3.4 & +0.5 & -1.1 & -0.1 \\
Goat $^{4}$ & 113 & +4.1 & +0.8 & +5.8 & 0.0 \\
Cow $^{5}$ & 769 & +2.1 & +0.2 & +2.2 & +0.1 \\
\hline
\end{tabular}

${ }^{1}$ Calcium salts of palm oil $(\mathrm{g} / \mathrm{d})$.

${ }^{2}$ From De Maria Ghionna et al. (1987) (low-yielding goats).

${ }^{3}$ From Martin et al. (1999) (early-lactation).

${ }^{4}$ From Rapetti et al. (2002) (midlactation).

${ }^{5}$ Six trials (review by Chilliard et al., 1993).

${ }^{6}$ Difference between fat supplemented and control groups.

$5 \%$ ), which escaped from ruminal biohydrogenation, were similar to those (about 3 to $4 \%$ ) observed in dairy cows (Chilliard et al., 2001). The partial protection by a casein-formaldehyde coating, which avoided the increase in oleic acid, did not avoid the increases in transC18:1 and 10-hydroxystearic acid, and increased slightly the transfer rate of $\mathrm{C} 20: 5$ and $\mathrm{C} 22: 6$ to goat milk (about 6 to 7\%) (Kitessa et al., 2001).

We recently compared (Table 7) the effects of dietary supplementation with either free oil or oilseeds, from either linseed (rich in C18:3) or sunflower (rich in C18:2). These four treatments sharply increased goat milk fat content ( +3 to $6 \mathrm{~g} / \mathrm{kg}$ ), but had very different effects on milk FA composition. Linseed oil had a greater effect on increasing the percentages of milk linolenic acid $(+325 \%)$ and cis 9 , trans 13 isomer of C18:2 (+350\%), whereas sunflower oil had more effect on milk linoleic $(+55 \%)$, trans-vaccenic $(+290 \%)$ and rumenic $(+283 \%)$ acids, probably undergoing the mechanisms indicated in Figure 2. trans-Vaccenic acid and RA and, surprisingly, polyunsaturated FA were more significantly increased by free oil than by oilseeds, whereas stearic and oleic acids were less affected. This suggests that biohydrogenation was less efficient when oil was added free than as part of the seeds, and that a low concentration of free oil (3 to $4 \%$ of diet DM) was sufficient to disturb rumen metabolism in a way that inhibited the biohydrogenation of its own FA, thus increasing the transfer of polyunsaturated and trans FA to milk.

The comparison of these two whole seeds with lupine seeds and whole soybeans showed that all four seeds sharply increased milk stearic and oleic acids. However, the highest oleic:stearic ratio was observed with lupine seeds, probably because they did not increase the secretion of polyunsaturated FA, contrary to the other seeds, which increased either C18:3 (linseeds) or C18:2 (sunflower and soya beans). Thus the mammary delta-9

Table 7. Milk yield and composition in goats fed a low forage diet ${ }^{1}$, supplemented or not with oils or whole crude oilseeds $^{2}$ (7 goats per group). (Y. Chilliard, J. Rouel, P. Capitan, E. Bruneteau, A. Ferlay, unpublished data).

\begin{tabular}{|c|c|c|c|c|c|c|c|}
\hline Diet & Control & $\begin{array}{l}\text { Linseed } \\
\text { oil }\end{array}$ & Linseeds & $\begin{array}{l}\text { Sunflower } \\
\text { oil }\end{array}$ & $\begin{array}{l}\text { Sunflower } \\
\text { seeds }\end{array}$ & $\begin{array}{l}\text { Lupine } \\
\text { seeds }\end{array}$ & Soybeans \\
\hline Milk yield $^{3}$ (kg/d) & 2.86 & 3.12 & 2.91 & 3.15 & 3.11 & 3.16 & 3.37 \\
\hline Fat content $(\mathrm{g} / \mathrm{kg})$ & $25.5^{\mathrm{a}}$ & $28.6^{\mathrm{b}}$ & $31.5^{\mathrm{b}}$ & $30.7^{\mathrm{b}}$ & $31.3^{\mathrm{b}}$ & $29.2^{\mathrm{b}}$ & $29.6^{\mathrm{b}}$ \\
\hline Protein content $(\mathrm{g} / \mathrm{kg})$ & $27.2^{\mathrm{a}}$ & $29.6^{\mathrm{bc}}$ & $30.0^{\mathrm{c}}$ & $28.2^{\mathrm{ab}}$ & $29.1^{\mathrm{bc}}$ & $29.0^{\mathrm{bc}}$ & $28.7^{\mathrm{abc}}$ \\
\hline Lactose content (g/kg) & $43.2^{\mathrm{a}}$ & $45.7^{\mathrm{b}}$ & $45.4^{\mathrm{b}}$ & $44.0^{\mathrm{ab}}$ & $43.1^{\mathrm{a}}$ & $44.6^{\mathrm{ab}}$ & $45.7^{\mathrm{b}}$ \\
\hline \multicolumn{8}{|c|}{ Fatty acids (w\% of total FA) } \\
\hline $\mathrm{C} 4+\mathrm{C} 6+\mathrm{C} 8$ & $7.9^{\mathrm{b}}$ & $7.5^{\mathrm{ab}}$ & $7.8^{\mathrm{b}}$ & $7.7^{\mathrm{b}}$ & $6.9^{\mathrm{a}}$ & $7.4^{\mathrm{ab}}$ & $7.1^{\mathrm{ab}}$ \\
\hline $\mathrm{C} 10+\mathrm{C} 12+\mathrm{C} 14$ & $24.9^{\mathrm{a}}$ & $16.3^{\mathrm{b}}$ & $18.0^{\mathrm{b}}$ & $17.3^{\mathrm{b}}$ & $16.9^{b}$ & $18.6^{\mathrm{b}}$ & $16.9^{\mathrm{b}}$ \\
\hline C16:0 & $25.8^{\mathrm{a}}$ & $16.9^{\mathrm{b}}$ & $19.0^{\mathrm{c}}$ & $18.2^{\mathrm{bc}}$ & $18.7^{\mathrm{c}}$ & $19.4^{\mathrm{c}}$ & $19.6^{\mathrm{c}}$ \\
\hline $\mathrm{O} \& \mathrm{BC}^{4}$ & $4.1^{\mathrm{a}}$ & $2.9^{\mathrm{c}}$ & $3.1^{\mathrm{bc}}$ & $2.8^{\mathrm{c}}$ & $3.0^{\mathrm{bc}}$ & $3.3^{b}$ & $2.8^{\mathrm{c}}$ \\
\hline C18:0 & $9.0^{\mathrm{a}}$ & $13.8^{\mathrm{b}}$ & $15.2^{\mathrm{bc}}$ & $13.0^{\mathrm{b}}$ & $15.9^{\mathrm{c}}$ & $13.5^{\mathrm{b}}$ & $16.6^{\mathrm{c}}$ \\
\hline C18:1 t11 & $1.0^{\mathrm{a}}$ & $2.9^{\mathrm{bc}}$ & $1.3^{\mathrm{a}}$ & $3.9^{\mathrm{c}}$ & $2.3^{\mathrm{b}}$ & $0.7^{\mathrm{a}}$ & $0.9^{\mathrm{a}}$ \\
\hline C18:1 c9 & $19.1^{\mathrm{a}}$ & $22.6^{\mathrm{ab}}$ & $24.7^{\mathrm{bcd}}$ & $20.8^{\mathrm{a}}$ & $23.9^{\mathrm{bc}}$ & $27.4^{\mathrm{d}}$ & $26.3^{\mathrm{cd}}$ \\
\hline C18:2 c9 t13 & $0.2^{\mathrm{a}}$ & $0.9^{\mathrm{c}}$ & $0.4^{\mathrm{b}}$ & $0.4^{\mathrm{b}}$ & $0.4^{\mathrm{b}}$ & $0.2^{\mathrm{a}}$ & $0.2^{\mathrm{a}}$ \\
\hline C18:2 c9 c12 & $2.2^{\mathrm{a}}$ & $2.2^{\mathrm{ab}}$ & $1.9^{\mathrm{b}}$ & $3.4^{\mathrm{c}}$ & $3.0^{\mathrm{d}}$ & $1.6^{\mathrm{e}}$ & $3.3^{\mathrm{cd}}$ \\
\hline C18:3 c9 c12 c15 & $0.4^{\mathrm{b}}$ & $1.7^{\mathrm{c}}$ & $1.2^{\mathrm{d}}$ & $0.5^{\mathrm{b}}$ & $0.5^{\mathrm{a}}$ & $0.6^{\mathrm{a}}$ & $0.4^{\mathrm{b}}$ \\
\hline C18:2 c9 t11 & $0.6^{\mathrm{a}}$ & $1.4^{\mathrm{c}}$ & $0.6^{\mathrm{a}}$ & $2.3^{\mathrm{b}}$ & $0.8^{\mathrm{d}}$ & $0.3^{\mathrm{e}}$ & $0.4^{\mathrm{ae}}$ \\
\hline Unidentified & 3.6 & 10.1 & 6.1 & 8.5 & 6.7 & 4.8 & 4.2 \\
\hline Atherogenicity index ${ }^{5}$ & $2.92^{\mathrm{a}}$ & $1.21^{\mathrm{a}}$ & $1.61^{\mathrm{b}}$ & $1.36^{\mathrm{c}}$ & $1.48^{\mathrm{bc}}$ & $1.72^{\mathrm{b}}$ & $1.52^{\mathrm{bc}}$ \\
\hline
\end{tabular}

\footnotetext{
${ }^{1}$ Natural grassland hay (30\%) and concentrates with or without oils or oilseeds $(70 \%)$.

${ }^{2} 3.4 \pm 0.6 \%$ added lipid in DM intake (supplemented-control). Linseed oil contains 6\% C16:0 + 17\% C18:1 $+15 \%$ C18:2 + 57\% C18:3; Sunflower oil contains 6\% C16:0 + 22\% C18:1 + 66\% C18:2; Lupine seeds contain $8 \% \mathrm{C} 16: 0+31 \% \mathrm{C} 18: 1+48 \% \mathrm{C} 18: 2+5 \% \mathrm{C} 18: 3$; Soybeans contain $12 \% \mathrm{C} 16: 0+21 \% \mathrm{C} 18: 1+52 \% \mathrm{C} 18: 2+$ 8\% C18:3.

${ }^{3}$ Data in same row with similar superscript letters do not differ at $P<0.05$ level.

${ }^{4}$ Odd and/or branched-chain FA (with 11 to 17 carbons).

${ }^{5}(\mathrm{C} 12+4$ C14 + C16):(sum of unsaturated FA) (from Ulbricht and Southgate, 1991).
} 
Table 8. Interactions between forage nature and vegetable oil supplementation (5 to 6\% of diet DM) on goat milk yield and composition (from Chilliard et al., 2002 and unpublished results). ${ }^{1}$

\begin{tabular}{|c|c|c|c|c|c|c|c|c|c|}
\hline \multirow[b]{2}{*}{ Oil } & \multicolumn{3}{|c|}{ Corn silage } & \multicolumn{3}{|c|}{ Alfalfa hay } & \multirow{2}{*}{$\begin{array}{l}P^{2} \\
\text { LO }\end{array}$} & \multirow{2}{*}{$\begin{array}{l}P^{3} \\
\text { OSO }\end{array}$} & \multirow[b]{2}{*}{$P$ int $^{4}$} \\
\hline & $\mathrm{C}$ & $\mathrm{LO}^{5}$ & $\mathrm{OSO}^{6}$ & $\mathrm{C}$ & $\mathrm{LO}^{5}$ & $\mathrm{OSO}^{6}$ & & & \\
\hline Milk yield (kg/d) & $3.62^{\mathrm{a}}$ & $3.98^{\mathrm{b}}$ & $3.48^{\mathrm{a}}$ & $3.47^{\mathrm{a}}$ & $3.62^{\mathrm{a}}$ & $3.45^{\mathrm{a}}$ & 0.05 & NS & NS \\
\hline Fat content (g/kg) & $34.4^{\mathrm{a}}$ & $34.6^{\mathrm{a}}$ & $36.6^{\mathrm{a}}$ & $29.8^{\mathrm{b}}$ & $37.2^{\mathrm{a}}$ & $35.2^{\mathrm{a}}$ & 0.01 & 0.01 & $0.01^{1}$ \\
\hline Protein content $(\mathrm{g} / \mathrm{kg})$ & $28.3^{\mathrm{a}}$ & $28.9^{\mathrm{abc}}$ & $29.8^{\mathrm{bc}}$ & $28.7^{\mathrm{ab}}$ & $29.5^{\mathrm{bc}}$ & $29.9^{c}$ & 0.1 & 0.01 & NS \\
\hline Lactose content $(\mathrm{g} / \mathrm{kg})$ & $45.6^{\mathrm{a}}$ & $47.1^{\mathrm{b}}$ & $47.5^{\mathrm{b}}$ & $42.8^{\mathrm{c}}$ & $44.8^{\mathrm{a}}$ & $45.3^{\mathrm{a}}$ & 0.01 & 0.01 & NS \\
\hline \multicolumn{10}{|c|}{ Fatty acids (w\% of total FA) } \\
\hline $\mathrm{C} 4: 0$ & $2.2^{\mathrm{ac}}$ & $2.9^{\mathrm{b}}$ & $2.6^{\mathrm{bc}}$ & $2.2^{\mathrm{ac}}$ & $2.4^{\mathrm{ac}}$ & $2.2^{\mathrm{a}}$ & 0.01 & 0.05 & $0.05^{\mathrm{ls}}$ \\
\hline C10:0 & $10.0^{\mathrm{a}}$ & $8.4^{\mathrm{bc}}$ & $7.4^{\text {be }}$ & $8.7^{\mathrm{c}}$ & $6.1^{\mathrm{de}}$ & $6.4^{\mathrm{e}}$ & 0.01 & 0.01 & NS \\
\hline C14:0 & $11.6^{\mathrm{a}}$ & $8.7^{b}$ & $8.4^{\mathrm{b}}$ & $12.2^{\mathrm{a}}$ & $7.5^{\mathrm{c}}$ & $8.4^{\mathrm{b}}$ & 0.01 & 0.01 & $0.01^{1}$ \\
\hline C16:0 & $28.8^{\mathrm{a}}$ & $18.8^{\mathrm{b}}$ & $18.6^{\mathrm{b}}$ & $31.1^{\mathrm{c}}$ & $18.1^{\mathrm{b}}$ & $17.8^{\mathrm{b}}$ & 0.01 & 0.01 & $0.01^{\mathrm{ls}}$ \\
\hline $\mathrm{O} \& \mathrm{BC}$ & $3.7^{\mathrm{a}}$ & $3.0^{\mathrm{b}}$ & $2.6^{\mathrm{c}}$ & $4.6^{\mathrm{d}}$ & $2.7^{\mathrm{c}}$ & $2.9^{\mathrm{bc}}$ & 0.01 & 0.01 & $0.01^{\mathrm{ls}}$ \\
\hline C18:0 & $7.5^{\mathrm{a}}$ & $9.2^{\mathrm{b}}$ & $13.7^{\mathrm{c}}$ & $6.0^{\mathrm{d}}$ & $10.8^{\mathrm{e}}$ & $12.7^{\mathrm{c}}$ & 0.01 & 0.01 & $0.01^{1}$ \\
\hline C18:1 t10 & $0.2^{\mathrm{a}}$ & $3.0^{\mathrm{b}}$ & $2.2^{\mathrm{b}}$ & $0.1^{\mathrm{a}}$ & $0.3^{\mathrm{a}}$ & $0.7^{\mathrm{a}}$ & 0.01 & 0.01 & $0.01^{\text {ls }}$ \\
\hline C18:1 t11 & $1.3^{\mathrm{ae}}$ & $6.6^{\mathrm{b}}$ & $3.4^{\text {ce }}$ & $0.4^{\mathrm{a}}$ & $9.1^{\mathrm{d}}$ & $2.3^{\mathrm{e}}$ & 0.01 & 0.01 & $0.01^{1}$ \\
\hline C18:1 c9 & $15.7^{\mathrm{a}}$ & $14.8^{\mathrm{a}}$ & $23.5^{\mathrm{b}}$ & $16.6^{\mathrm{a}}$ & $16.0^{\mathrm{a}}$ & $27.9^{\mathrm{c}}$ & NS & 0.01 & $0.05^{\mathrm{s}}$ \\
\hline $\mathrm{C} 18: 2$ c9c12 & $2.0^{\mathrm{a}}$ & $1.5^{\mathrm{b}}$ & $1.4^{\mathrm{c}}$ & $2.3^{\mathrm{d}}$ & $1.7^{\mathrm{e}}$ & $1.6^{\mathrm{b}}$ & 0.01 & 0.01 & NS \\
\hline $\mathrm{C} 18: 3$ c9c12c15 & $0.32^{\mathrm{a}}$ & $0.68^{\mathrm{b}}$ & $0.17^{\mathrm{c}}$ & $0.60^{\mathrm{b}}$ & $1.38^{\mathrm{d}}$ & $0.42^{\mathrm{e}}$ & 0.01 & 0.01 & 0.01 \\
\hline C18:2 c9 t11 & $0.59^{\text {ad }}$ & $2.25^{\mathrm{b}}$ & $0.79^{\text {ad }}$ & $0.34^{\mathrm{a}}$ & $3.24^{\mathrm{c}}$ & $1.01^{\mathrm{d}}$ & 0.01 & 0.01 & $0.01^{\mathrm{ls}}$ \\
\hline Atherogenicity index ${ }^{7}$ & $3.4^{\mathrm{a}}$ & $1.7^{\mathrm{b}}$ & $1.6^{\mathrm{bc}}$ & $3.5^{\mathrm{a}}$ & $1.5^{\mathrm{bc}}$ & $1.4^{\mathrm{c}}$ & 0.01 & 0.01 & $0.1^{\mathrm{s}}$ \\
\hline
\end{tabular}

\footnotetext{
${ }^{1} \mathrm{C}, \mathrm{LO}, \mathrm{OSO}, \mathrm{O}, \mathrm{BC}=$ control, linseed oil, oleic sunflower oil, odd-numbered FA, branched-chain FA, respectively; 12 goats per group, except hay-control group $(\mathrm{n}=10)$; data in same row with similar superscript letters do not differ at $P<0.05$ level.

${ }^{2,3}$ Probability for LO or OSO effect, respectively.

${ }^{4}$ Probability for forage-oil interaction (l or s indicates significant interaction for LO or OSO, respectively).

${ }^{5}$ Linseed oil contains 6\% C16:0 + 17\% C18:1 + 15\% C18:2 + 57\% C18:3.

${ }^{6}$ Oleic sunflower oil contains 4\% C16:0 + 83\% C18:1 + 7\% C18:2.

${ }^{7}(\mathrm{C} 12: 0+4 \mathrm{C} 14: 0+\mathrm{C} 16: 0):($ Sum of unsaturated FA).
}

desaturase activity was probably higher with lupine seed, because desaturase activity is inhibited by polyunsatured FA, and/or because lupine seeds tended to decrease trans-vaccenic acid (Table 7). This later decrease could also explain why lupine seeds decreased milk RA. Among the four seeds, only sunflower seeds increased trans-vaccenic acid and RA (Table 7). This suggests that when biohydrogenation occurred on the polyunsaturated FA released from linseeds or soya beans it occurred slowly but almost completely. These results on effects of soybeans are in agreement with observations in dairy cows by Morales et al. (2000) who suggested that polyunsaturated FA from roasted whole soybeans, compared to those from tallow, were, in part, protected against biohydrogenation and that the other part was slowly but completely hydrogenated, since both $\mathrm{C} 18: 2$ and C18:0, but not trans-C18:1, increased in milk fat.

Lupine seeds FA were totally and completely hydrogenated and these seeds could even bring special (nitrogenous?) compounds, which could increase the biohydrogenation of polyunsaturated FA from the basal diet. Thus these three seeds (linseeds, soybeans, lupine seeds) would need to be physically treated (ground, heated, extruded,...) in order to specifically increase trans FA and RA in goat milk. On the contrary, oil from whole untreated sunflower seeds was probably more rapidly released and interacted with rumen microflora, in a way that significantly increased trans-vaccenic. However, the increase in RA was much lower than when free sunflower oil was used. Further research is needed to understand the mechanisms that could explain these differences.

The trial presented in Table 7 thus shows that the four whole seeds studied are not efficient when used to increase goat milk RA, in contrast to the use of free linseed or sunflower oils. Feeding free canola oil also increased $(+204 \%)$ goat milk total CLA content (Mir et al., 1999).

Interaction between forages and oil supplements. The RA content of goat milk fat was lower during winter than during summer, when animals received fresh grass (Figure 6). The effect of grass feeding on milk RA is probably due to its high content in linolenic acid (cf. Figure 2). Furthermore, it is likely that different types of winter diets (hay vs. corn silage) are not equivalent for goat milk RA content, and that they could also interact differently with dietary fat supplements. We tested this possibility recently, comparing the effects of either linseed oil or high oleic sunflower oil, added to either hay or corn silage-based diets (Table 8). 


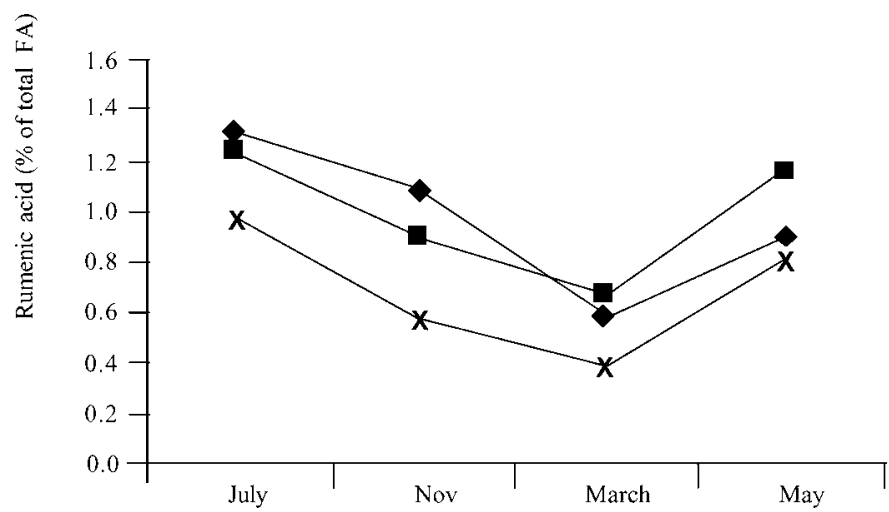

Figure 6. Rumenic acid (cis-9, trans-11 C18:2) content of ruminant milk fat in different seasons (from Jahreis et al., 1999). $\bullet$, ewe; $\mathbf{\square}$, cow; $\mathbf{X}$, goat.

Total DMI was higher for alfalfa hay-based diet (2.9 $\mathrm{kg} / \mathrm{d})$ than for corn silage $(2.2 \mathrm{~kg} / \mathrm{d})$ and was not affected by oil addition. In the absence of added lipids, hay diet (compared to corn silage) lowered milk fat and lactose contents, C8:0, C10:0, and C18:0 percentages and increased C16:0, branched-chain and odd-numbered FA, C14:1, C16:1, C17:1, linoleic, and linolenic acid percentages (Table 8, and results not shown). Compared with control diets, linseed oil addition increased milk yield, and fat and lactose contents, C4:0, C18:0, trans-10 C18:1, trans-vaccenic, rumenic and linolenic acid percentages, and lowered C10:0 to C16:1, branched-chain and odd-numbered FA percentages, and the atherogenicity index. Effects of linseed oil addition on C4:0, C6:0 and trans-10 C18:1 were higher when combined with the corn silage diet, while effects on milk fat content and C14:0 to linolenic acid and RA (except trans-10 C18:1, oleic and linoleic acids) were higher with the hay diet. The effect on RA (+853\% with hay diet) was spectacular. Compared with control diets, high oleic sunflower oil addition increased milk fat, protein and lactose contents, C4:0, C18:0, oleic, trans-vaccenic and RA percentages, and lowered C8:0 to C16:1, branchedchain and odd-numbered FA, linoleic and linolenic acid percentages, and the atherogenicity index. Effects of high oleic sunflower oil addition on C4:0 and trans-10 C18:1 were greater with the corn silage diet, while effects on C16:0, C16:1, oleic acid, branched-chain and odd-numbered FA and RA were higher with the hay diet. The trans-10 cis-12 CLA isomer was never present in significant amounts, whatever the diet used in Table 8 .

Thus the differences between hay and corn silage diets were small. High oleic sunflower oil addition sharply increased stearic and oleic acid percentages. Linseed oil addition sharply increased trans-vaccenic

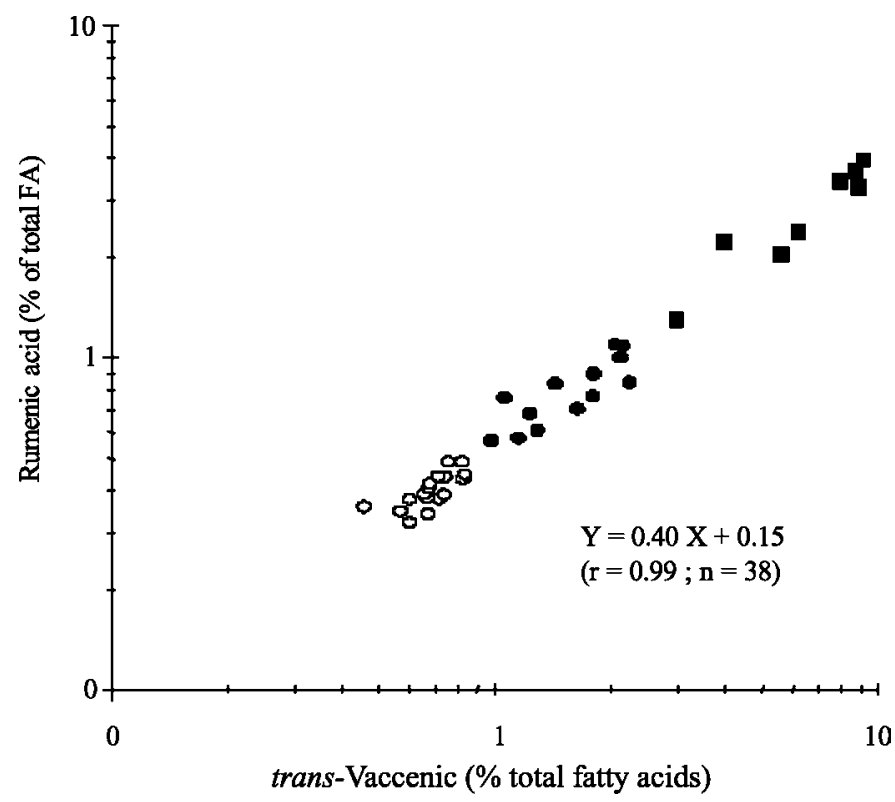

Figure 7. Relationship between the contents of trans-vaccenic and rumenic acids in goat milk. $\bigcirc$ Hay-based diets (either without lipid supplementation or with untreated lupin seeds or soybeans). Haybased diets (either without lipid supplementation or supplemented with high-oleic sunflower oil or untreated linseeds or sunflower seeds) or corn silage-based diets (either without lipid supplementation or with high-oleic sunflower oil). $\quad$ Hay or corn silage-based diets, supplemented with either linseed oil or sunflower oil. Each point is the mean of values from 7 to 16 goats $(\mathrm{N}=401$ milks from 38 experimental groups). (Adapted from data presented in Tables 7, 8, and unpublished results).

and RA percentages, and the effects were higher with hay diet. Important interactions between forage and oil effects were observed. Furthermore, any increase in RA was systematically (for 38 different diets) accompanied by a 2.5 -fold higher increase in trans-vaccenic acid (Figure 7), as in dairy cows (Griinari and Bauman, 1999). This implies that the potential effects on human health of both CLA and trans-C18:1 isomers have to be evaluated together with care (e.g., Jensen, 2002) in order to predict the putative effects of lipid supplementation on goat milk fat nutritional quality. A sharp decrease in the atherogenicity index of goat milk fat was observed for the two vegetable oils, whatever the forage. These results are an illustration of how dietary factors can broadly modify goat milk FA composition and have potential effects on its quality for human nutrition.

In other respects, the sensorial characteristics of goat milk and cheeses made from this trial were subject to several changes (Gaborit et al., 2002). Intensities of descriptors were generally higher for hay than for corn silage diets, and higher for hay + linseed oil and corn silage + high oleic sunflower oil, indicating several types of interaction between forages and oils used in this study. Lipid supplementation, especially linseed oil, de- 
creased goat flavor (in agreement with data on milk lipase and lipolysis, see below) and increased negative flavors. Metallic/oxidized and fishy flavors could result from greater oxidation of free polyunsaturated FA following lipid supplementation, especially when using linseed oil (oxidation of C18:3). Thus, it could be difficult to simultaneously optimize goat milk sensorial and nutritional qualities, although the addition of antioxidants could be helpful in reducing unsaturated FA oxidation.

Conclusion. Despite differences in the quantitative responses (milk yield and milk fat content), the changes in milk FA composition after lipid supplementation are very similar in goats (see above) and cows (reviews by Palmquist et al., 1993; Griinari and Bauman, 1999; Chilliard et al., 1993, 2001). It is likely that specific changes in minor FA that play an important role in the inhibition of mammary lipogenesis (such as trans-10 C18:1 or trans-10 cis-12 CLA in cows, Bauman and Griinari, 2001), and that are not well-known in goats, could partially explain between-species differences. However, the sharp increase in trans-10 C18:1 due to corn silage-vegetable oil interactions (Table 8) did not result in a decrease in goat milk fat content, contrary to observations in cows. Nevertheless, the trans-10 C18:1 could be involved in the lack of positive effect of oil supplementation on goat milk fat content when corn silage was used, whereas oil supplementation increased sharply milk fat content when hay was used (Table 8). Changing diet composition can allow rapid and efficient changes in goat milk FA composition, but potential effects on other aspects of the quality of caprine dairy products, such as taste, flavor, nutritive and health value for consumers, warrant further investigations.

\section{LIPASE AND LIPOLYSIS}

\section{The Lipolytic System}

Milk fat lipolysis is the hydrolysis of fat globule triglycerides into free FA. "Spontaneous lipolysis" in cold, stored milk is due to the action of milk lipoprotein lipase (LPL), which can be stimulated ("induced lipolysis") by agitation, foaming or temperature changes. During long-term storage of dairy products, there could also be a significant contribution of microbial lipolysis, whereas milk endogenous LPL is easily destroyed by mild heat treatment (Chilliard and Lamberet, 1984).

Milk fat lipolysis and lipase (or LPL) activity are two distinct phenomena, although both result in the hydrolysis of triglycerides. Milk fat lipolysis generally takes place at $4^{\circ} \mathrm{C}$, at natural milk $\mathrm{pH}$, in the presence of biochemical factors naturally occuring in milk. It is generally lower than $1.0 \mathrm{mmol}$ released $\mathrm{FA} / 24 \mathrm{~h} / \mathrm{L}$ of goat milk (Chilliard, 1982). Milk LPL activity is mea- sured as maximal potential activity on an artificial lipid emulsion, at 37 or $39^{\circ} \mathrm{C}$, at alkaline $\mathrm{pH}$, in the presence of apoprotein activators from blood serum. It is generally higher than $20 \mu \mathrm{mol} / \mathrm{h} / \mathrm{ml}$ of goat milk (Chilliard, 1982). Thus potential LPL activity is more than 500 times higher than spontaneous lipolysis in goat milk.

The lipolytic system differs considerably between goat (Bjorke and Castberg, 1976; Chilliard et al., 1984; Azzara and Dimick, 1989), cow (Cartier and Chilliard, 1990, 1994) and human (Castberg and Hernell, 1975; Neville et al., 1991) milks. Spontaneous lipolysis is not correlated to LPL activity in bovine milk, and lipolysis remains generally low despite the very high LPL activity of this milk. This could be due to the presence of inhibitors in bovine milk (Cartier et al., 1990), as well as to the fact that bovine milk LPL is largely bound to casein micelles, thus decreasing enzyme-fat substrate interactions. On the contrary, large proportions of human and goat milk LPL are bound to cream, which could explain that milk lipolysis is well correlated to milk LPL activity in these two species. This can be related to the lack of effect of heparin addition on goat milk lipolysis, contrary to its strong positive effect on cow milk lipolysis due to the release of casein-bound LPL by heparin (Chilliard et al., 1984). Furthermore, blood serum (a specific activator of LPL) increased lipolysis more in goat than in cow milk, except when goat milk total LPL activity was extremely low and became limiting (Chilliard et al., 1984). Goat milk serum proteose peptone fraction inhibited spontaneous (Chilliard et al., 1984) and induced (Arora and Joshi, 1994) lipolysis of goat milk, as was similarly observed for cow milk (Anderson, 1981; Cartier et al., 1990).

The development of goat flavor in cold, stored fresh milk is due to free FA, especially free C6:0 to C9:0 and more specifically volatile branched-chain C9 and C10 as 4-methyl- and 4-ethyl-C8, which are more abundant in small ruminant than in bovine milk fat ( $\mathrm{Ha}$ and Lindsay, 1993; Lamberet et al., 2001). The high concentrations of total branched-chain FA in the milk fat of ruminant species results mainly from microbial metabolism of branched-chain amino acids in the rumen, since leucine and isoleucine give rise to iso-valeric and 2methyl butyric acids; the corresponding acyl-CoA could be used as a primer in the elongating process to form the iso and anteiso series up to C17. Furthermore, goat milk contains minor volatile branched-chain FA with one methyl or ethyl group on carbon 4 (Ha and Lindsay, 1990a; Lamberet et al., 1996; Alonso et al., 1999). These FA probably arise from tissue metabolism of propionate and butyrate absorbed from the rumen, such metabolism probably differing between bovine and caprine species. Interestingly, two of these minor FA (4-methyloctanoic acid which was first found with 4-methylnonan- 


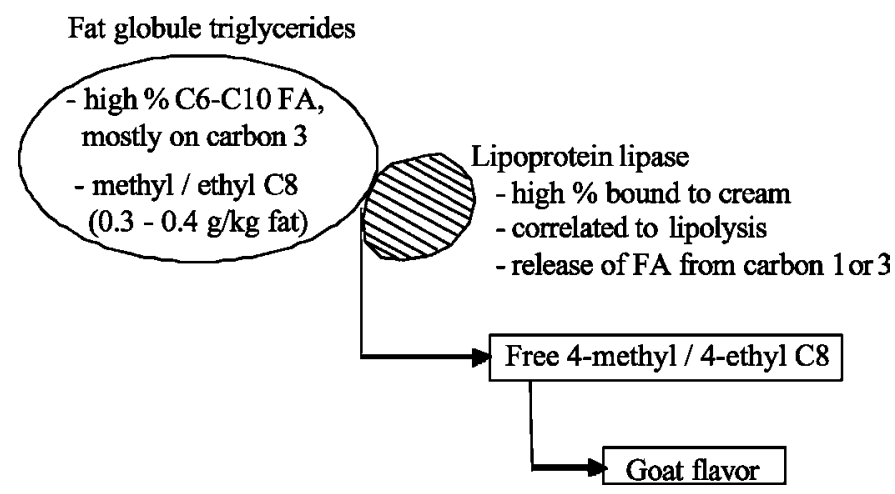

Figure 8. Fatty acids, lipolysis, and goat flavor (from Chilliard, 1982; Ha and Lindsay, 1993; Lamberet et al., 1996).

oic acid in mutton meat (Wong et al., 1975), and 4ethyloctanoic acid) are involved in goat flavor. $\mathrm{Ha}$ and Lindsay (1990b) proposed pathways for their formation in ruminant fat, by analogy with descriptions of fat from uropygial glands in waterfowl (e.g., Rainwater and Kolattukudy, 1982). But nothing is known of the way in which such a synthesis is regulated within the different tissues in ruminants. For example, according to Sugiyama et al. (1986), a homologous series of 4-ethyl branched-chain FA, in free and bound forms, is the main fat component from neck sebaceous glands of adult buck. 4-Ethyloctanoic acid, which can be considered as a pheromone, represents less than $5 \%$ of this series while 4-ethyldodecanoic acid accounts for about half the total amount. The presence of such a series leads to suppose that addition of ethylmalonyl-CoA at different stages of the FA elongation process takes place in the sebaceous gland cells. In goat milk, only the presence of 4-ethyloctanoic acid was reported, and this FA has the lowest flavor threshold value determined until now for FA (Brennand et al., 1989; Karl et al., 1994).

Thus, the combination of goat milk FA composition, triglyceride structure (i.e., high proportion of C6-C10 FA esterified on carbon 3) and LPL characteristics could explain the link between LPL, lipolysis and goat flavor in caprine milk (Figure 8). Furthermore, it should be pointed out that goat flavor, which is regarded sometimes as a positive, sometimes as a negative feature in cheeses or milk, appears at lipolysis levels much lower than those responsible for the rancid-butyric flavor (Lamberet et al., 1996, 2001 and unpublished results).

\section{Genetic Factors}

There are large differences between caprine Norvegian (Bjorke and Castberg, 1976; Skjevdal, 1979), Alpine (Chilliard, 1982; Chilliard et al., 1984), and Saanen
(Skjevdal, 1979; Y. Chilliard and C. Delouis, quoted by Chilliard et al., 1986) breeds in the levels of LPL activity and spontaneous lipolysis. LPL activity was 70,35 , and $21 \mu \mathrm{mol}$ of $\mathrm{FA} / \mathrm{h}$ per milliliter, and lipolysis $4.6,0.5$, and $1.1 \mathrm{mmol}$ of FFA/24 h per liter, in Norwegian, Alpine, and Saanen goats, respectively. Furthermore, both parameters were positively affected by selection of Norwegian goats for milk flavor (Bakke et al., 1977).

These breed or genetic effects could be related in part to the casein $\alpha$-s1 genotype. Indeed, milks from goats with different alleles of the casein $\alpha$-s1 gene present different protein, casein, and fat contents (Grosclaude et al., 1994; Table 3). Interestingly, goats of FF genotype secrete a milk with lower fat content and higher levels of LPL activity, spontaneous lipolysis and goat flavor than goats of AA genotype (Table 3; Delacroix-Buchet and Lamberet, 2000). Thus, selecting goats for milk flavor is probably the reason for which the frequency of null alleles is very high in Norway (Vegarud et al., 1999). Negative intergoat correlations were found consistently between milk fat content and goat flavor (review by Delacroix-Buchet and Lamberet, 2000). Furthermore, milk fat C16:0 percentage was higher in FF genotypes (Delacroix-Buchet et al., 1996; Lamberet et al., 1996) in agreement with a positive interanimal correlation between C16:0 percentage and goat flavor (Bakke et al., 1977; Astrup et al., 1985).

The creaming ability is also related to the casein $\alpha$ s1 genotype. Indeed, an 11\% decrease in milk fat content was followed by a $49 \%$ decrease in the fat content of the cream from FF compared with AA goats (Table 3 ). This could be related either to differences in the size or composition of milk fat globules and in the amount of cytoplasmic fragments or to other factors linked to differences in secretory mechanisms between AA and FF genotypes, that could explain in part the occurrence of apocrine milk secretion in the goat (Neveu et al., 2002).

\section{Physiological Factors}

Goat milk flavor (reviews by Skjevdal, 1979; Delacroix-Buchet and Lamberet, 2000), lipolysis and LPL activity (Table 4 and Figure 9) were at their highest after the lactation peak, and were low before wk 4 and after wk 30 of lactation. This confirms that the latter two parameters are well correlated in goats, unlike in cows in which milk LPL activity decreased as lipolysis increased during late lactation (Chazal and Chilliard, 1986). This effect of lactation stage in cows was in fact an effect of pregnancy stage (Chazal and Chilliard, 1986) linked to estrogens (Cartier and Chilliard, 1994) and/or progesterone (Chilliard et al., 1997). One reason for the lack of increase in milk lipolysis during late 


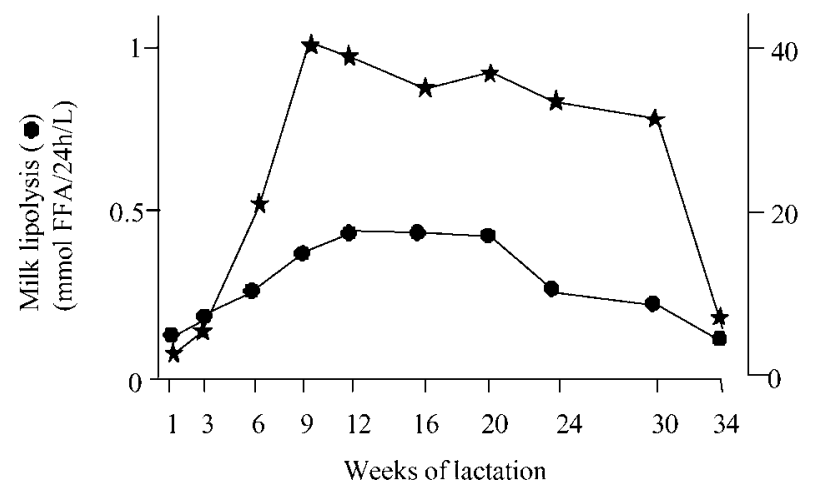

Figure 9. Effects of lactation stage on Alpine goat milk lipolysis and lipoprotein lipase (LPL) activity (from Chilliard et al., 1981).

lactation in goats could be that fecundation occurs later, due to the shorter pregnancy in this species. The involvement of sex steroid hormones in the maturation of the milk lipolytic system is also suggested by the fact that the normal increase of milk LPL activity during early lactation was delayed in goats hormonally induced into lactation without being previously pregnant (Figure 10). In other respects, there is an interaction between lactation stage and $\alpha$-s1 casein genotype: the increase of lipolysis as lactation advances was more pronounced and significant in goats with $\mathrm{E}, \mathrm{F}$, or $\mathrm{O}$ alleles (Table 4).

Hourly milking sharply increased goat milk LPL activity and sodium concentration, but only in some animals (Azzara and Dimick, 1989). Massage of the mam-

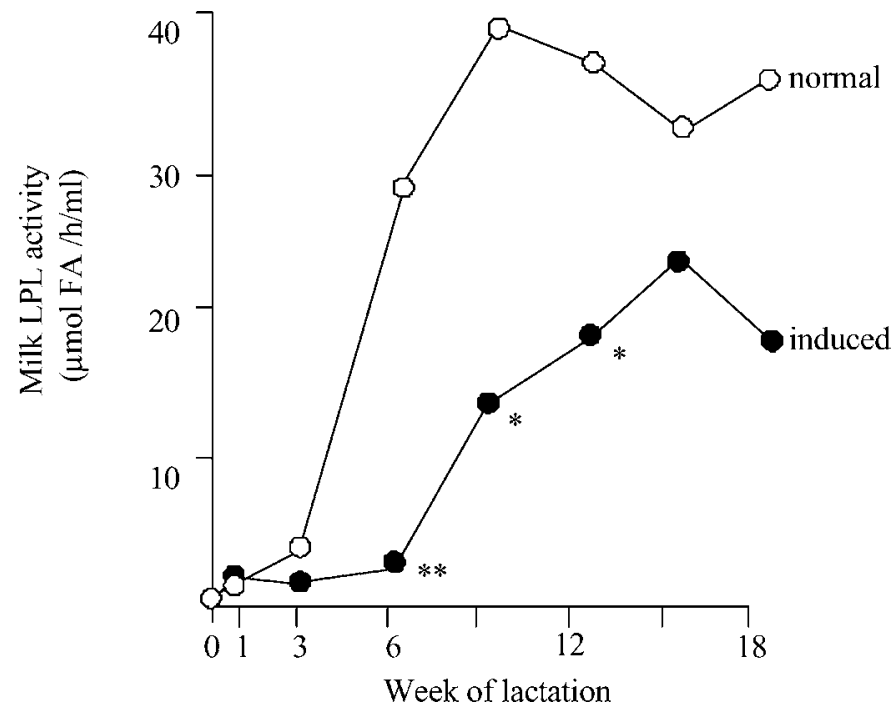

Figure 10. Changes in milk lipoprotein lipase (LPL) activity in normal goats (after pregnancy) or goats hormonally induced into lactation (from Chilliard et al., 1986).

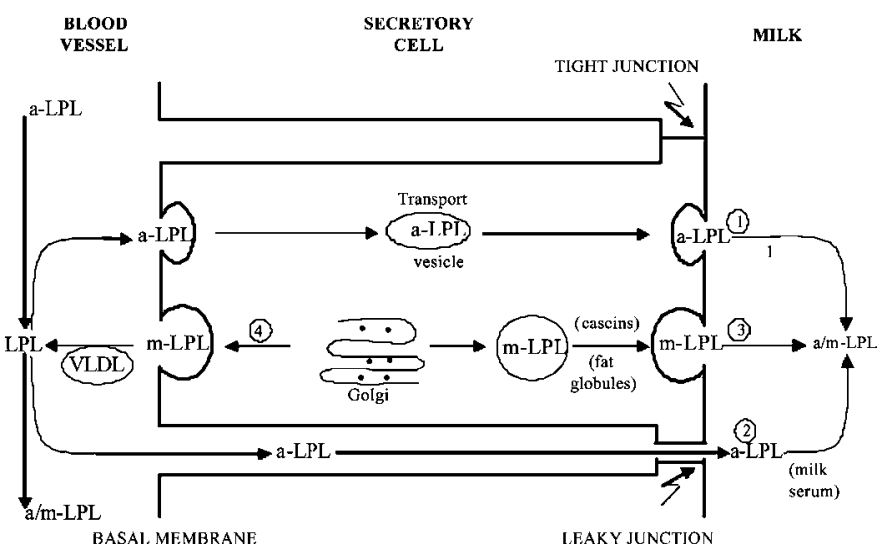

Figure 11. Putative mechanisms for the origin of milk lipoprotein lipase (LPL) (from Chilliard et al., 1979b and present review; Olivecrona, 1980; Azzara and Dimick, 1989). Milk-LPL could arise from adipose or other body tissues (a-LPL) which could be secreted either by endocytosis of LPL at the basal membrane, followed by transport in secretory vesicle and exocytosis at the apical membrane (1) or by paracellular leakage into the milk serum (2). Another putative origin is the partition of mammary synthesized LPL (m-LPL) between secretion into milk with either caseins or fat globules (3) and migration to basal membrane (4) followed by interaction with VLDL substrate and/or leakage into the blood stream. $\mathrm{a} / \mathrm{m}-\mathrm{LPL}=\mathrm{LPL}$ from adipose and/or mammary origin.

mary gland or oxytocine injection was necessary to cause increased milk LPL activity in nonresponding goats. This suggests that paracellular leakage across mammary epithelium of LPL circulating in the blood (Figure 11) was increased. Furthermore, hourly milking compared with twice daily milking increased the percentage of milk LPL distributed in the serum fraction (Azzara and Dimick, 1989), thus suggesting that this milk fraction could contain mainly LPL from blood origin in goats (Figure 11). A similar effect of milking frequency was observed recently in dairy cows in which once daily milking decreased milk LPL activity compared with twice daily milking (Rémond et al., 2002).

\section{Nutritional Factors}

The distribution of protected sunflower oil (C18:2rich) decreased goat milk LPL activity and the level of spontaneous lipolysis (Figure 12). This result was recently confirmed with unprotected C18:1-, C18:2-, and C18:3-rich oils: milk LPL activity and spontaneous lipolysis decreased sharply in goats fed hay- or corn silage-based diets when fat was added (5 to 6\% of DMI from either regular or high-oleic sunflower oil or linseed oil, Figure 13). This matches with the negative correlation observed between goat milk flavor and polyunsaturated FA content (Skjevdal, 1979), and with the decrease in goat flavor in milk and cheeses from animals of Table 8 receiving lipid supplements (Gaborit et al., 


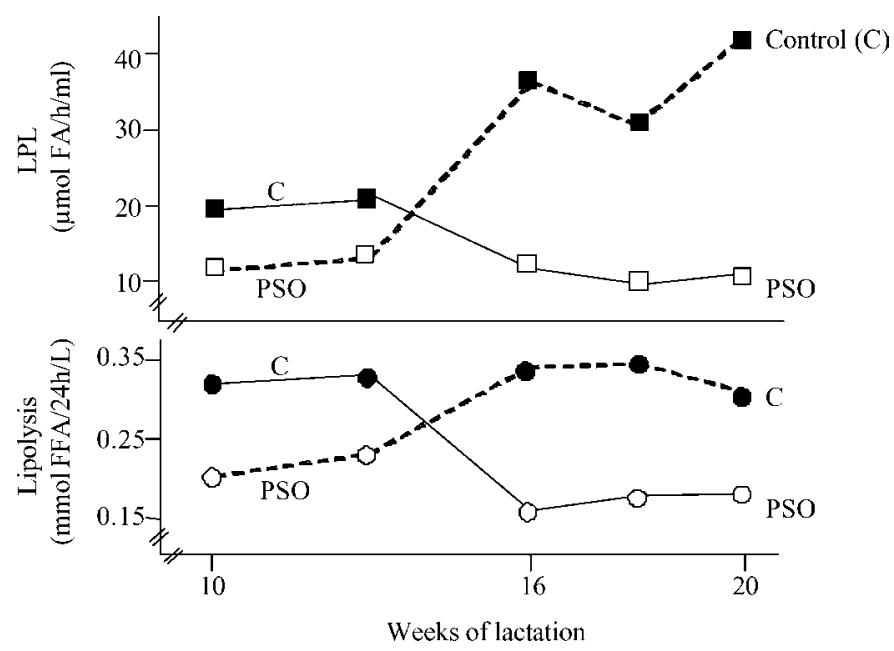

Figure 12. Effects of feeding protected sunflower oil (PSO, 6\% of the concentrate), on Alpine goat milk lipoprotein lipase (LPL) activity and spontaneous lipolysis (from Chilliard et al., 1981).

2002). It can be observed in Figure 13 that the effect of lipid supplementation was less important on milk spontaneous lipolysis than on milk LPL activity, and it can be predicted that milk lipolysis would only increase when milk LPL activity is higher than 15 to $18 \mu \mathrm{mol} /$ $\mathrm{h}$ per milliliter. It could be hypothesized that milk LPL activity decreased when supplemental lipids were fed because mammary LPL was directed towards the basal membrane of secretory cells, where it is needed to allow the uptake of blood triglycerides (Figure 11). Conversely, the higher LPL activity in milk of animals with the FF genotype (Table 3) could be related to the lower flow of fat secretion, thus decreasing the need for LPL at the basal membrane and increasing the availability of LPL for secretion into milk for a given level (constitutive of the lactating status) of mammary LPL synthesis.

Goat milk LPL activity decreased sharply during fasting and rebounded at the beginning of the refeeding period (Figure 14). Milk spontaneous lipolysis did not change markedly and was poorly correlated to milk LPL activity during fasting-refeeding, whereas the free FA content of freshly drawn milk increased during fasting (Figure 14), probably due to a direct passage of blood NEFA to the milk when their concentration was increased by body fat mobilization. As the mammary gland LPL activity did not significantly change during fasting-refeeding (Figure 15), it may be thought either that mammary LPL was partitioned differently between basal membrane and milk when the nutritional status changed, or that blood LPL arising from adipose tissues contributed less to milk LPL secretion because it was decreased in adipose tissues during fasting (Figures 11 and 15). These observations can be related to

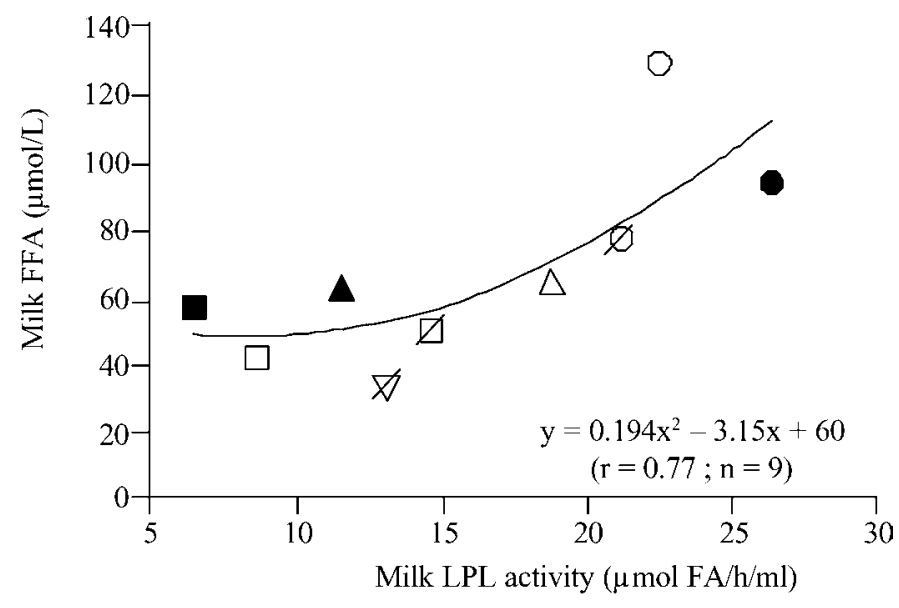

- $\boldsymbol{\Delta}=$ cornsilage (10-week treatments)

$\bigcirc \square \triangle$ = alfalfa hay (10-week treatments)

$\varnothing \square \varnothing 7=$ natural grassland hay (4-week treatments)

$\bigcirc \varnothing \supset$ = noadded oil

$\square \square \square=$ linseed oil (5-6\% of diet DM)

$\triangle \boldsymbol{\Delta}=$ high oleic sunflower oil (5-6\% of diet DM)

$\not=$ sunflower oil $(6 \%$ of diet DM)

Figure 13. Effects of dietary forages and lipid supplements on goat milk free fatty acid (FFA) content (after $1 \mathrm{~d}$ storage at $4^{\circ} \mathrm{C}$ ) versus lipoprotein lipase (LPL) activity (Y. Chilliard, J. Rouel, J. M. Chabosseau, P. Gaborit, L. Bernard and J. Fléchet, unpublished results; 9 to 15 goats per treatment group; the r-value was 0.54 for the 115 individual milks).

the negative effect of fasting and to the positive effect of insulin on human milk LPL activity (Neville et al., 1991).

A putative link between adipose tissue LPL and milk LPL activity is also suggested by the positive correlation $(\mathrm{r}=+0.61)$ observed in lactating goats (Table 9).
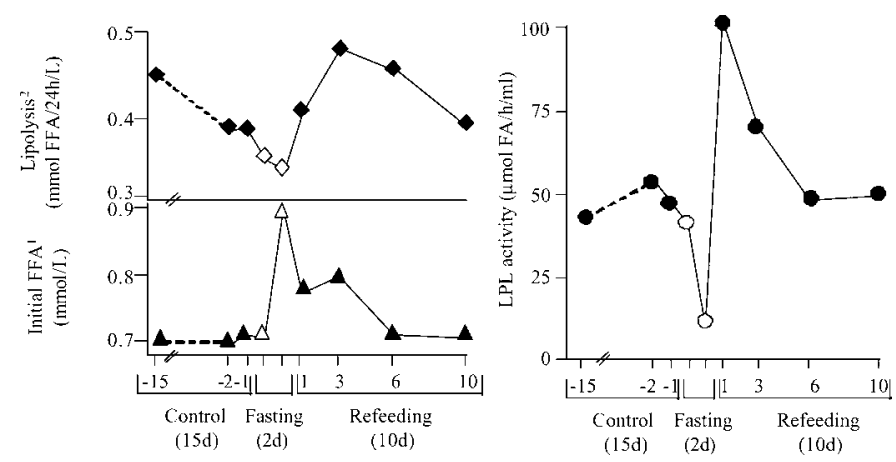

Figure 14. Effects of fasting and refeeding on Alpine goat milk lipolysis and lipoprotein lipase (LPL) activity (from Chilliard et al., 1981). ${ }^{1}$ Level of free fatty acids (FFA) in fresh milk. ${ }^{2}$ Increase in milk FFA during 24-h storage at $4^{\circ} \mathrm{C}$. 


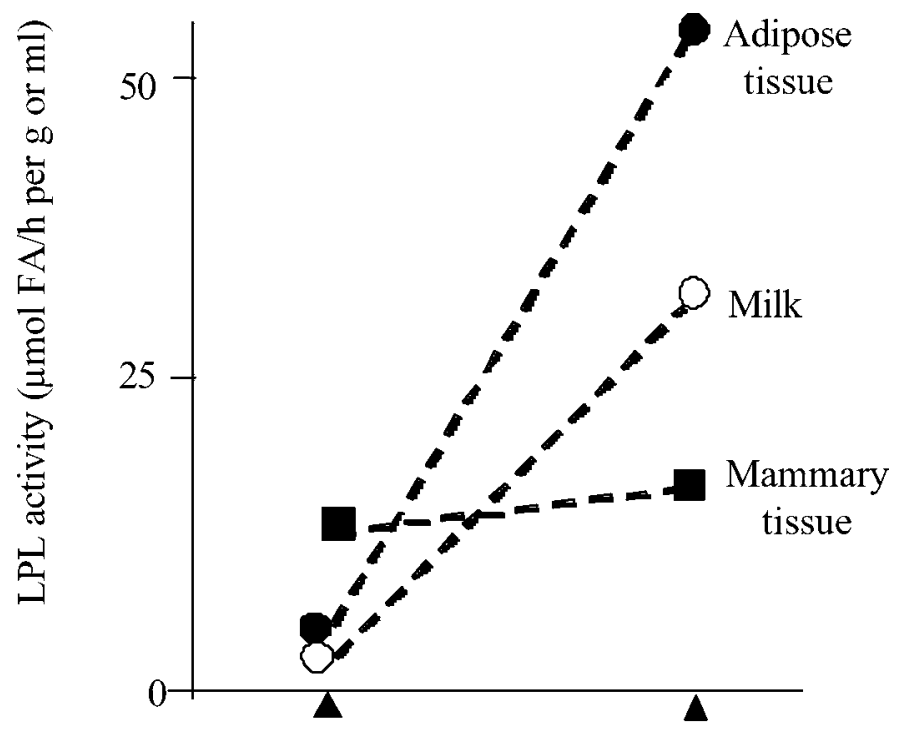

$48 \mathrm{~h}$ fasted

$7 \mathrm{~d}$ refed

Figure 15. Effect of fasting and refeeding on lipoprotein lipase (LPL) activities in the lactating goat (from Chilliard et al., 1979b).

This relationship was mainly due to intra-goat and between-lactation stage correlation. Indeed, adipose tissue LPL and other lipogenic activities were low in highyielding goats at the beginning of lactation, and then increased when animals returned to a positive energy balance, after 3 or 4 mo of lactation (Figure 16). Simultaneously, milk LPL activity followed a similar pattern (Figures 9 and 10), whereas mammary LPL activity did not change significantly (Chilliard et al., 1986). In other respects, the strongest correlation $(\mathrm{r}=-0.70)$ was between milk LPL activity and milk fat C16:0 percentage (Table 9). It can be hypothesized that there is a mechanistic link between the physiological or nutritional regulation of the chain-length of synthesized FA and the synthesis and secretion of mammary LPL. This observation is also in agreement with the fact that feeding

Table 9. Correlations between goat milk lipoprotein lipase (LPL) activity and production or metabolic traits. ${ }^{1}$

\begin{tabular}{ll}
\hline Parameter & $\mathrm{r}(\mathrm{n}=27)^{2}$ \\
\hline DMI & +0.55 \\
Milk yield & +0.44 \\
Milk fat content & -0.33 \\
Milk C 16:0 (\% of total FA) & -0.70 \\
Mammary RNA/DNA & +0.41 \\
Mammary LPL & $\mathrm{NS}$ \\
Adipose tissue LPL & +0.61 \\
\hline
\end{tabular}

\footnotetext{
${ }^{1}$ From Chilliard (1985).

${ }^{2} 9$ goats at 3,9 , and 18 wk of lactation ( 4 normal and 5 hormonallyinduced).
}

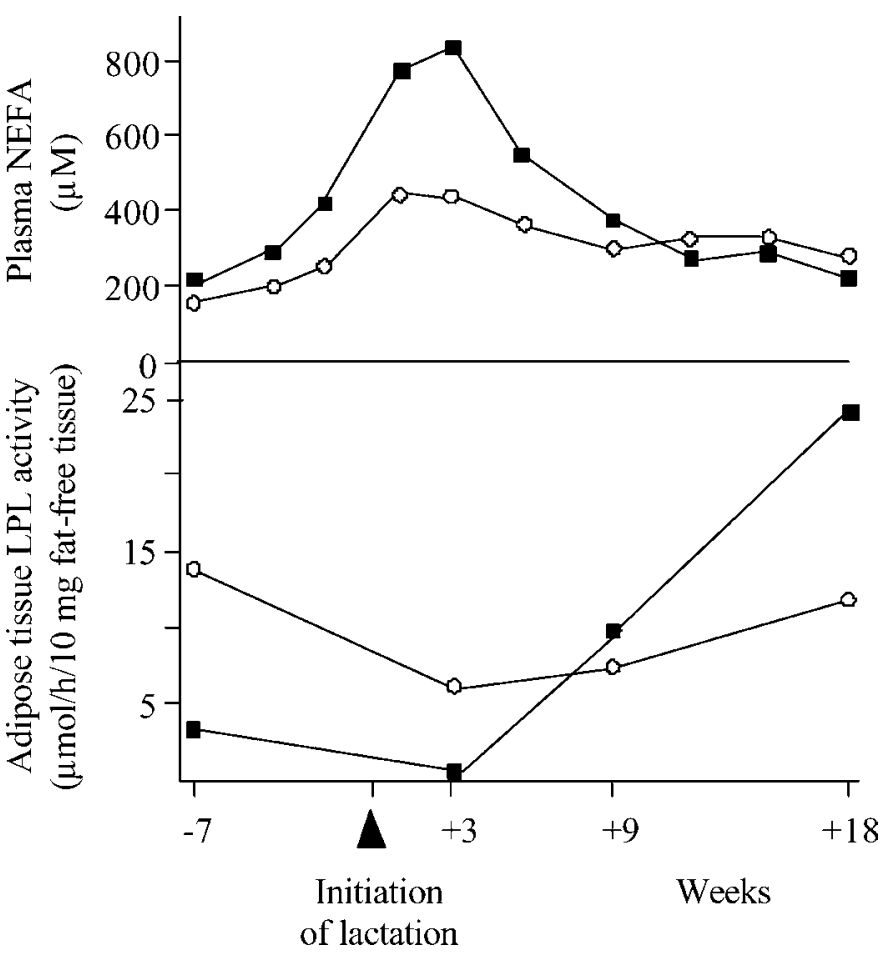

Figure 16. Changes in plasma NEFA and adipose tissue lipoprotein lipase (LPL) activity in four late pregnant-early lactation goats (Ш) or in four nonpregnant goats hormonally induced into lactation (O) (from Chilliard, 1985 and Chilliard et al., 1986).

C16:0 to goats tended to decrease milk lipolysis and goat flavor, whereas there was surprisingly a positive interindividual correlation between $\mathrm{C} 16: 0$ and goat flavor (Astrup et al., 1985).

The results reviewed here on physiological and nutritional variations of goat milk LPL activity are similar to what was observed in cow milk (Table 10). On the contrary, lipolysis in bovine milk was not correlated to LPL activity, and responded differently to physiological factors compared with observations in goat milk (Table

Table 10. Physiological and nutritional variations of milk lipoprotein lipase (LPL) activity and spontaneous lipolysis. ${ }^{1}$

\begin{tabular}{lllllll}
\hline & \multicolumn{2}{c}{ LPL } & & \multicolumn{2}{c}{ Lipolysis } \\
\cline { 2 - 3 } \cline { 6 - 7 } & Cow & Goat & & Cow & Goat \\
\hline Early lactation & - & - & & - & - \\
Late lactation & - & - & & + & - \\
Late pregnancy & - & $?$ & & ++ & $?$ \\
Milking frequency & + & + & & + & $?$ \\
Underfeeding & - & - & & + & - \\
Protected lipid feeding & - & - & & $+/-$ & - \\
\hline
\end{tabular}

${ }^{1}$ From Chilliard (1982 and present review) for goats, Chilliard and Lamberet (1984), Chazal and Chilliard (1986 and unpublished results), Azzara et al. (1987), Rémond et al. (2002 and unpublished results) for cows. $(+/-)=$ increase/decrease (respectively). 
10). Thus, important differences exist between goat and cow lipolytic systems as well as in the physiological regulation of milk lipolysis, even though the regulation of milk LPL activity was similar in the two species.

\section{CONCLUSIONS}

The responses of milk yield and fat content to lipid supplementation differ widely between the goat and the cow, even though the response of milk FA composition is similar, at least for major FA, including trans-vaccenic RA. Although the physiological and nutritional regulation of milk LPL activity is similar between the goat and the cow, their lipolytic systems differ. This probably explains why the physiological regulation and the husbandry factors of spontaneous lipolysis differ significantly between the two species. Peculiarities of goat milk FA composition and lipolytic system play an important role in the development of goat flavor.

Quantitative and qualitative aspects of milk quality cannot always be increased simultaneously. For example, lipid supplementation could improve the efficiency of goat cheese yield and its FA profile but decrease its sensorial quality. In other respects, the polymorphism of the casein $\alpha$-s1 gene in goats presents an interesting model to study the mechanistic links between mammary protein and fat secretions, as well as the opposite regulations of goat milk fat and LPL secretion and their relationships with the development of goat flavor. The present and future knowledge on genetic, physiological, and nutritional factors regulating goat milk FA composition and lipolytic system will be helpful in the management procedures of goat husbandry to optimize the quantitative and qualitative (nutritional, sensorial, technological, etc.) aspects of goat dairy products.

\section{ACKNOWLEDGMENTS}

We thank C. Leroux, L. Bernard, A. Delacroix-Buchet and F. Bocquier for helpful discussions during preparation of the manuscript, P. Capitan, E. Bruneteau, P. Caugnon, L. Huguet, J. M. Chabosseau, A. Combeau and A. Ollier for taking part in unpublished experiments, F. Polidori for helping us in compiling Italian results, and P. Béraud and Y. Fournier for secretarial assistance.

\section{REFERENCES}

Alonso, L., J. Fontecha, L. Lozada, M. J. Fraga, and M. Juarez. 1999. Fatty acid composition of caprine milk: Major, branched-chain, and trans fatty acids. J. Dairy Sci. 82:878-884.

Anderson, M. 1981. Inhibition of lipolysis in bovine milk by proteose peptone. J. Dairy Res. 48:247-252.

Arora, S., and V. K. Joshi. 1994. Effect of addition of proteose-peptone (PP) fraction to goat milk on the inhibition of induced lipolysis. Indian J. Dairy Sci. 47:875-879.
Astrup, H. N., T. A. Steine, and A. M. Robstad. 1985. Taste, free fatty acids and fatty acid content in goat milk. Acta Agric. Scand. 35:315-320.

Azzara, C. D., and P. S. Dimick. 1989. Paracellular leakage of lipoprotein lipase across the mammary epithelium of the goat. J. Dairy Sci. 72:1159-1168.

Azzara, C. D., P. S. Dimick, and W. Chalupa. 1987. Milk lipoprotein lipase activity during long-term administration of recombinant bovine somatotropin. J. Dairy Sci. 70:1937-1940.

Bakke, H., T. Steine, and A. Eggum. 1977. Flavor score and content of free fatty acids in goat milk. Acta Agric. Scand. 27:245-249.

Baldi, A., F. Cheli, C. Corino, V. Dell'Orto, and F. Polirodi. 1992. Effects of feeding calcium salts of long chain fatty acids on milk yield, milk composition and plasma parameters of lactating goats. Small Rumin. Res. 6:3-310.

Barber, M. C., R. A. Clegg, M. T. Travers, and R. G. Vernon. 1997. Lipid metabolism in the lactating mammary gland. Biochim. Biophys. Acta 1347:101-126.

Bartocci, S., G. M. Terzano, A. Omero, and A. Borghese. 1988. Utilizzazione del seme integrale di cotone nella dieta die capre in lattazione: Nota 1. Ann. Ist. Sper. Zootec. 21:135-146.

Bas, P., Y. Chilliard, P. Morand-Fehr, A. Rouzeau, and N. Mandran. 1987. Composition des principaux tissus adipeux de la chèvre Alpine en fin de lactation. Ann. Zootech. 36:361-374.

Bauman D. E., and C. L. Davis. 1974. Biosynthesis of milk fat. Vol II, Pages 31-75 in Lactation, a Comprehensive Treatise. B. L Larson and V. R. Smith, eds. Academic Press, New York.

Bauman, D. E., and J. M. Griinari. 2001. Regulation and nutritional manipulation of milk fat: Low-fat milk syndrome. Livest. Prod. Sci. 70:15-29.

Bickerstaffe, R., D. E. Noakes, and E. F. Annison. 1972. Quantitative aspects of fatty acid biohydrogenation, absorption and transfer into milk fat in the lactating goat, with special reference to the cis- and trans-isomers of octadecenoate and linoleate. Biochem. J. 130:607-617.

Bjorke, K., and H. B. Castberg. 1976. Lipolytic activity in goat's milk. N. Eur. Dairy J. 8:296-304.

Bocquier, F., J. Rouel, A. Domalain, and Y. Chilliard. 2000. Effect of concentrate/dehydrated alfalfa ratio on milk yield and composition in Alpine dairy goats fed hay based diets. Cah. Options Méditérr. 52:99-101.

Brennand, C. P., J. Kim Ha, and R. C. Lindsay. 1989. Aroma properties and thresholds of some branched-chain and other minor volatile fatty acids occurring in milk fat and meat lipids. J. Sensory Stud. 4:105-120.

Brown-Crowder, I. E., S. P. Hart, M. Cameron, T. Sahlu, and A. L. Goetsch. 2001. Effects of dietary tallow level on performance of Alpine does in early lactation. Small Rumin. Res. 39:233-241.

Caja, G., and F. Bocquier. 2000. Effects of nutrition on the composition of sheep's milk. Cah. Options Méditerr. 52:59-74.

Calderon, I., E. J. De Peters, N. E. Smith, and A. A. Franke. 1984. Composition of goat's milk: Changes within milking and effects of a high concentrate diet. J. Dairy Sci. 67:1905-1911.

Cartier, P., and Y. Chilliard. 1990. Spontaneous lipolysis in bovine milk: combined effects of nine characteristics of native milk. J. Dairy Sci. 73:1178-1186.

Cartier, P., and Y. Chilliard. 1994. Effects of estradiol injection on milk composition, milk fat lipolysis and lipase activity in the nonpregnant dairy cow. Annales de Zootechnie, 43 (Suppl. 1), 45S.

Cartier, P., Y. Chilliard, and D. Paquet. 1990. Inhibiting and activating effects of skim milks and proteose peptone fractions on bovine milk spontaneous lipolysis and purified lipoprotein lipase activity. J. Dairy Sci. 73:1173-1177.

Castberg, H. B., and O. Hernell. 1975. Role of serum-stimulated lipase in lipolysis in human milk. Milchwissenschaft 30:721-723.

Chazal, M. P., and Y. Chilliard. 1986. Effect of stage of lactation, stage of pregnancy, milk yield and herd management on seasonal variation in spontaneous lipolysis in bovine milk. J. Dairy Res. 53:529-538.

Chilliard, Y. 1982. Variations physiologiques des activités lipasiques et de la lipolyse spontanée dans les laits de vache, de chèvre et de femme: revue bibliographique. Lait 62:1-31 and 126-154. 
Chilliard, Y. 1985. Métabolisme du tissu adipeux, lipogenèse mammaire et activités lipoprotéine-lipasiques chez la chèvre au cours du cycle gestation-lactation. Thèse Doc. Etat ès-Sci., Univ. Paris 6, 134 pp., 1323 réf.

Chilliard, Y. 1993. Dietary fat and adipose tissue metabolism in ruminants, pigs and rodents: A review. J. Dairy Sci. 76:3897-3931.

Chilliard,Y., and F. Bocquier. 1993. Effects of fat supplementation on milk yield and composition in dairy goats and ewes. Proc. 5th Int. Symp. "La qualita nell produzioni dei piccoli ruminanti".(Camera di Commercio Industria Artigianato Agricultura di Varese, Italia, 3 Dicembre 1993) 61-78.

Chilliard, Y., and F. Bocquier. 2000. Direct effects of photoperiod on lipid metabolism, leptin synthesis and milk secretion in adult sheep in Proc. 9. Int. Symp. on Ruminant Physiology. Pretoria (ZAF), 18-22 Oct. 1999. CAB International 2000. Ruminant Physiology: Digestion, Metabolism, Growth and Reproduction (Ed. P. B. Cronjé), Chap. 12:205-223.

Chilliard, Y., P. Cartier, D. Levieux, and A. Ollier. 1997. Effets d'injections d'oestradiol et de progestérone sur la production, la composition et la lipolyse du lait de vache non gravide. Rencontres Rech. Rumin. 4:35.

Chilliard, Y., J. M. Chabosseau, J. Rouel, P. Capitan, C. Gominard, P. Gaborit, P. Juanéda, and A. Ferlay. 2002. Interactions between forage nature and sunflower or linseed oil supplementation on goat milk fatty acids of interest for human nutrition. Multi-Function Grasslands: Quality Forages, Animal Products and Landscapes. J. L. Durand, J. C. Emile, C. Huyghe and G. Lemaire, eds. Proc. 19th Gen. Mtg. of the Eur. Grassl. Fed. La Rochelle, France, 27-30 May 2002, Grassl. Sci. Eur. 7:548-549.

Chilliard, Y., C. Delouis, M. C. Smith, D. Sauvant, and P. MorandFehr. 1986. Mammary metabolism in the goat during normal or hormonally-induced lactation. Reprod. Nutr. Dev. 26:607-615.

Chilliard, Y., and M. Doreau. 1997. Influence of supplementary fish oil and rumen-protected methionine on milk yield and composition in dairy cows. J. Dairy Res. 64:173-179.

Chilliard, Y., M. Doreau, G. Gagliostro, and Y. Elmeddah. 1993. Addition de lipides protégés (encapsulés ou savons de calcium) à la ration de vaches laitières. Effets sur les performances et la composition du lait. INRA Prod. Anim. 6:139-150.

Chilliard, Y., A. Ferlay, and M. Doreau. 2001. Effect of different types of forages, animal fat or marine oils in cow's diet on milk fat secretion and composition, especially conjugated linoleic acid (CLA) and polyunsaturated fatty acids. Livest. Prod. Sci. 70:31-48.

Chilliard, Y., A. Ferlay, R. M. Mansbridge, and M. Doreau. 2000. Ruminant milk fat plasticity: nutritional control of saturated, polyunsaturated, trans and conjugated fatty acids. Ann. Zootech. 49:181-205.

Chilliard, Y., G. Gagliostro, J. Fléchet, J. Lefaivre, and I. Sebastian. 1991. Duodenal rapeseed oil infusion in early and midlactation cows. 5. Milk fatty acids and adipose tissue lipogenic activities. J. Dairy Sci. 74:1844-1854.

Chilliard, Y., and G. Lamberet. 1984. La lipolyse dans le lait: les différents types, mécanismes, facteurs de variation, signification pratique. Lait 64:544-578.

Chilliard, Y., P. Morand-Fehr, G. Durand, and D. Sauvant. 1979a. Evolution de l'activité métabolique du tissu adipeux chez la chèvre au cours des deux premiers mois de lactation. Relation avec la sécrétion lactée. Bull. Acad. Vét. France 52:417-422.

Chilliard, Y., D. Sauvant, J. Hervieu, M. Dorléans, and P. MorandFehr. 1977. Lipoprotein lipase activity and composition of omental adipose tissue as related to lipid metabolism of the goat in late pregnancy and early lactation. Ann. Biol. Anim. Bioch. Biophys. 17:1021-1033.

Chilliard, Y., D. Sauvant, and P. Morand-Fehr. 1979b. Goat mammary, adipose and milk lipoprotein lipases. Ann. Rech. Vét. 10:401-403.

Chilliard, Y., D. Sauvant, P. Morand-Fehr, and C. Delouis. 1987. Relations entre le bilan énergétique et l'activité métabolique du tissu adipeux de la chèvre au cours de la première moitié de la lactation. Reprod. Nutr. Dévelop. 27:307-308.
Chilliard, Y., G. Selselet-Attou, P. Bas, and P. Morand-Fehr. 1981. Facteurs influençant la lipolyse du lait de chèvre. Pages 332350 in 6 Journées de la Recherche Ovine et Caprine. Toulouse (France). Ed. ITOVIC SPEOC, Paris, France.

Chilliard, Y., G. Selselet-Attou, P. Bas, and P. Morand-Fehr. 1984. Characteristics of lipolytic system in goat milk. J. Dairy Sci. 67:2216-2223.

Chiofalo, V., G. Savoini, P. Micari, A. Zumbo, V. Bontempo, and M. Ziino. 1993. Impiego di differenti fonti energetiche per l'alimentazione della pecora : effetti sulle caratteristiche quanti-qualitative del latte. Atti $10^{\circ}$ Congr. Naz. ASPA:339-344.

Daccord, R. 1987. Effect of addition of animal or vegetable fat to a hay based diet on digestibility and nitrogen balance in the lactating goat. Ann. Zootech. 36:329. (Abstr.)

Delacroix-Buchet, A., C. Degas, G. Lamberet, and L. Vassal. 1996. Influence des variants $\mathrm{AA}$ et $\mathrm{FF}$ de la caséine $\alpha \mathrm{s} 1$ caprine sur le rendement fromager et les caractéristiques des fromages. Lait 76:217-241.

Delacroix-Buchet, A., and G. Lamberet. 2000. Sensorial properties and typicity of goat dairy products. 7th Int. Conf. on Goats, Tours, France. 15-21 May 2000. Tome 2:559-563.

Delage, J., and P. M. Fehr. 1967. Influence des lipides alimentaires sur la sécrétion des acides gras par la mamelle de chèvre. I. Influence de la teneur du régime en lipides sur le taux butyreux du lait et sa composition en acides gras. Ann. Biol. Anim. Biochim. Biophys. 7:437-444.

DeMaria Ghionna, C., S. Bartocci, G. M. Terzano, and A. Borghese. 1987. Acidi grassi salificati con calcio nell'alimentazione di capre in lattazione : I effectto sulla produzione, sul contenuto di grasso e di protein del latte. Ann. Ist. Sper. Zootec. 20:231-242.

Destaillats, F., R. L. Wolff, D. Precht, and J. Molkentin. 2000. Study of individual trans- and cis-16:1 isomers in cow, goat, and ewe cheese fats by gas-liquid chromatography with emphasis on the trans-3 isomer. Lipids 35:1027-1032.

Gaborit, P., K. Raynal, A. Lauret, J. M. Chabosseau, J. Rouel, and Y. Chilliard. 2002. Flavor of goat milk and cheeses according to feeding alfalfa hay or maize silage with oleic sunflower or linseed oil supplementation. Multi-Function Grasslands: Quality Forages, Animal Products and Landscapes. J. L. Durand, J. C. Emile, C. Huyghe and G. Lemaire, eds. Proc. 19th Gen. Mtg. of the Eur. Grassl. Fed., La Rochelle, France, 27-30 May 2002, Grassl. Sci. Eur. 7:562-563.

Gelaye, S., and E. A. Amoah. 1988. Energy requirement of lactating goats. J. Anim. Sci. 66(Suppl. 1):39-40.

Glass, R. L., H. A. Troolin, and R. Jenness. 1967. Comparative biochemical studies of milks. IV. Constituent fatty acids of milk fats. Comp. Biochem. Physiol. 22:415-425.

Griinari, J. M., and D. E. Bauman. 1999. Biosynthesis of conjugated linoleic acid and its incorporation into meat and milk in ruminants. Pages 180-200 in Advances in Conjugated Linoleic Acid Research. Vol. 1. M. P. Yurawecz, M. M. Mossoba, J. K. G. Kramer, M. W. Pariza, and G. L. Nelson, eds. Am. Oil Chem. Soc. Press, Champaign, IL.

Grosclaude, F., G. Ricordeau, P. Martin, F. Remeuf, L. Vassal, and J. Bouillon. 1994. Du gène au fromage: Le polymorphisme de la caséine $\alpha$-s1 caprine, ses effets, son évolution. INRA Prod. Anim. 7:3-19.

Guesnet, P., J. M. Antoine, J. B. Rochette de Lempdes, A. Galent, and G. Durand. 1993. Polyunsaturated fatty acid composition of human milk in France: Changes during the course of lactation and regional differences. Eur. J. Clin. Nutr. 47:700-710.

Gulati, S. K., E. B. Byers, Y. G. Byers, J. R Ashes, and T. W. Scott. 1997. Effect of feeding different fat supplements on the fatty acid composition of goat milk. Anim. Feed Sci. Technol. 66:159-164.

Gulati, S. K., S. M. Kitessa, J. R. Ashes, E. Fleck, E. B. Byers, Y. G. Byers, and T. W. Scott. 2000. Protection of conjugated linoleic acids from ruminal hydrogenation and their incorporation into milk fat. Anim. Feed Sci. Technol. 86:139-148.

Ha, J. K., and R. C. Lindsay. 1990a. Method for the quantitative analysis of volatile free and total branched-chain fatty acid in cheese and milk fat. J. Dairy Sci. 73:1988-1999. 
Ha, J. K., and R. C. Lindsay. 1990b. Distribution of volatile branchedchain fatty acids in perinephric fats of various red meat species. Lebensm.-Wiss. u.-Technol. 23:433-440.

Ha, J. K, and R. C. Lindsay. 1993. Release of volatile branched-chain and other fatty acids from ruminant milk fats by various lipases. J. Dairy Sci. 76:677-690.

Hadjipanayiotou, M. 1999. Feeding ensiled crude olive cake to lactating Chios ewes, Damascus goats and Friesian cows. Livest. Prod. Sci. 59:61-66.

Hart, S. P. 2000. Nutrition for the high producing dairy doe. J. Anim. Sci. 78 (Suppl.1):8.

Jahreis, G., J. Fritsche, P. Möckel, F. Schöne, U. Möller, and H. Steinhart. 1999. The potential anticarcinogenic conjugated linoleic acid, cis-9, trans-11 C18:2, in milk of different species: cow, goat, ewe, sow, mare, woman. Nutr. Res. 19:1541-1549.

Jarrige, R., M. Petit, and M. Tissier. 1978. Reproduction, gestation, lactation. Pages 229-243 in Alimentation des Ruminants, INRA, Publ. 78000 Versailles (France).

Jensen, R. G. 1989. The Lipids of Human Milk. C.R.C. Press, Inc., Boca Raton, FL.

Jensen, R. G. 2002. The composition of bovine milk lipids: January 1995 to December 2000. J. Dairy Sci. 85:295-350.

Karl, V., J. Gutser, E. Dietrich, B. Mass, and A. Mosandl. 1994. Stereoisomeric flavor compounds LXVIII. 2-, 3-, and 4-alkylbranched acids, part 2: Chirospecific analysis and sensory evaluation. Chirality 6:427-434.

Kitessa, S. M., S. K. Gulati, J. R. Ashes, E. Fleck, T. W. Scott, and P. D. Nichols. 2001. Utilisation of fish oil in ruminants. II. Transfer of fish oil fatty acids into goats' milk. Anim. Feed. Sci. Technol. 89:201-208.

Knudsen, J., and I. Grunnet. 1982. Transacylation as a chain-termination mechanism in fatty acid synthesis by mammalian fatty acid synthetase. Biochem. J. 202:139-143. 766.

Lamberet, G., C. Degas, A. Delacroix-Buchet, and L. Vassal. 1996. Influence de caractères lies aux allèles $\mathrm{A}$ et $\mathrm{F}$ de la caséine $\alpha \mathrm{s} 1$ caprine sur la flaveur chèvre: Fabrications fromagères avec échange de protéines et de matières grasses. Lait 76:349-361.

Lamberet, G., A. Delacroix-Buchet, and C. Degas. 2001. Intensité de la lipolyse initiale des laits de chèvre et perception de l'arôme "chèvre" dans les fromages. Pages 130-139 in Proc. Technical Symp. 7th Int. Conf. Goats: Recent Advances on Goat Milk Quality, Raw Material for Cheesemaking. (ITPLC Ed.). Poitiers, France, 20 May 2000.

Lanzani, A., P. Bondioli, C. Mariani, E. Fedeli, F. Polidori, V. Dell'Orto, C. Corino, A. Guisi, G. Contarini, and E. Ferro. 1985. Prove di impiego di un "Liquid Feed" addizionato con grassi protetti in capre nell'alimentazione di capre in lattazione. Atti 6è Congr. Naz. A. S. P. A.:87-92.

LeDoux, M., A. Rouzeau, P. Bas, and D. Sauvant. 2002. Occurrence of trans-C18:1 fatty acid isomers in goat milk: Effect of two dietary regimens. J. Dairy Sci. 85:190-197.

Léger, C., D. Sauvant, J. Hervieu, and F. Ternois. 1994. Influence of duodenal infusions of EPA and DHA on the lipidic milk secretion of the dairy goat. Ann. Zootech. 43:297.

Linzell, J. L. 1973. Innate seasonal oscillations in the rate of milk secretion in goats. J. Physiol. 230:225-233.

Lu, C. D. 1993. Implication of feeding isoenergetic diets containing animal fat on milk composition of Alpine does during early lactation. J. Dairy Sci. 76:1137-1147.

Martin, L., P. Rodriguez, A. Rota, A. Rojas, M. R. Pascual, D. Patón, and J. Tovar. 1999. Effect of protected fat supplementation to lactating goats on growth and fatty acid composition of perirenal fat in goat kids. Anim. Sci. 68:195-200.

McDonald, I. W., and T. W. Scott. 1977. Foods of ruminant origin with elevated content of polyunsaturated fatty acids. World Rev. Nutr. Dietetics 26:144-207.

Mir, Z., L. A. Goonewardene, E. Okine, S. Jaegar, and H. D. Scheer. 1999. Effect of feeding canola oil on constituents, conjugated linoleic acid (CLA) and long chain fatty acids in goats milk. Small Rumin. Res. 33:137-143.

Morales, M. S., D. L. Palmquist, and W. P. Weiss. 2000. Milk fat composition of Holstein and Jersey cows with control or depleted copper status and fed whole soybeans or tallow. J. Dairy Sci. 83:2112-2119.

Morand-Fehr, P., P. Bas, and D. Sauvant. 1987. Influence de la nature et de la quantité de lipides ajoutés à la ration sur la sécrétion de lait et de matière grasse chez la chèvre. Reprod. Nutr. Dévelop. 27:309-310.

Morand-Fehr, P., P. Bas, D. Sauvant, J. Hervieu, and Y. Chilliard. 1986. Influence de la nature de l'aliment concentré sur le métabolisme des chèvres en fin de gestation et en début de lactation. Reprod. Nutr. Dévelop. 26:349-350.

Morand-Fehr, P., Y. Chilliard, and D. Sauvant. 1982. Goat milk and its compounds: Secretory mechanisms and influence of nutritional factors. Pages 113-121 in Proc. 3. Int. Conf. on Goat Production and Disease. Tucson. AZ.

Morand-Fehr, P., D. Sauvant, and P. Bas. 1984a. Utilisation des matières grasses chez les ruminants. Expériences sur chèvres laitières. Pages D1-D21 in CAAAA: Peut-on et comment utiliser les matières grasses dans les rations des vaches laitières, Nov. 8, ADEPRINA, Paris. France.

Morand-Fehr, P., D. Sauvant, and P. Bas. 1984b. Effet de la fraction grasse des graines de soja sur les performances des chèvres laitières. 35th Annual Meeting of the EAAP. The Hague The Netherlands.

Morand-Fehr, P., M. R. Sanz Sampelayo, Y. V. Fedele, Y. Le Frileux, M. Eknaes, P. H. Schmidely, S. Giger Reverdin, P. Bas, R. Rubino, O. Havrevoll, and D. Sauvant. 2000a. Effect of feeding on the quality of goat milk and cheeses in 7 Int. Conf. on Goats, Tours, France. 15-21 May 2000. Tome 1:53-58.

Morand-Fehr, P., J. Tessier, F. Meschy, and D. Sauvant. 2000b. Effect of roughage level and source in diets on the risk of reversing fat and protein percentages in goat milk. Cah. Options Méditerr. 52:115-118.

Neveu, C., A. Riaublanc, G. Miranda, J. F. Chich and P. Martin. 2002. Is the apocrine milk secretion process observed in the goat species rooted in the perturbation of the intracellular transport mechanism induced by defective alleles at the $\alpha$ s1-Cn locus? Reprod. Nutr. Dev. 42:163-172.

Neville, M. C., L. J. Waxman, D. R. Jensen, and R. H. Eckel. 1991. Lipoprotein lipase in human milk: compartmentalization and effect of fasting, insulin and glucose. J. Lipid Res. 32:251-257.

Nudda A, G. Battacone, R. Bencini, and G. Pulina. 2002. Nutrition and Milk Quality. Ch. 8. Dairy Sheep Feeding and Nutrition. G. Pulina, ed. Avenue media Ed., Bologna, Italia, pp. 197-228.

Olivecrona T. 1980. Biochemical aspects of lipolysis in bovine milk. Bull. Int. Dairy Fed. Doc. 118:19-26.

Palmquist, D. L., 1991. Influence of source and amount of dietary fat on digestibility in lactating cows. J. Dairy Sci. 74:1354-1360.

Palmquist, D. L., A. D. Beaulieu, and D. M. Barbano. 1993. Feed and animal factors influencing milk fat composition. J. Dairy Sci. 76:1753-1771.

Palmquist, D. L., and T. C. Jenkins. 1980. Fat in lactation rations for dairy: A review. J. Dairy Sci. 63:1-14.

Parodi, P. W. 1999. Conjugated linoleic acid and other anticarcinogenic agents of bovine milk fat. J. Dairy Sci. 82:1339-1349.

Polidori, F., A. Baldi, F. Cheli, and G. Pulina. 1991. Alimentazione e qualita' del latte caprino. IIIè Simposio Internazionale: Qualità del latte ovino-caprino. Pages 105-134. Ed. G. Enne, and G. F. Greppi, Varese. Italia.

Precht, D., and J. Molkentin. 1999. C18:1, C18:2 and C18:3 trans and cis fatty acid isomers including conjugated cis $\Delta 9$, trans $\Delta 11$ linoleic acid (CLA) as well as total fat composition of German human milk lipids. Nahrung 43:233-244.

Rainwater, D. L., and P. E. Kolattukudy. 1982. Purification and characterization of acyl-CoA carboxylase from uropygial gland which produces multimethyl-branched acids and evidence for its identity with avian acetyl-CoA carboxylase. Arch. Biochem. Biophys. 213:372-383.

Rapetti, L., G. M. Crovetto, G. Galassi, A. Sandrucci, G. Succi, A. Tamburini, and G. Battelli. 2002. Effect of maize, rumen-protected fat and whey permeate on energy utilisation and milk fat composition in lactating goats. Ital. J. Anim. Sci. 1:43-53. 
Rémond, B., S. Aubailly, Y. Chilliard, D. Dupont, D. Pomiès, and M. Petit. 2002. Combined effects of once-daily milking and feeding level in early lactation on production and enzyme activities of milk, and nutritional status, in Holstein cows. Anim. Res. 51: 101-117.

Rouel, J., F. Bocquier, and Y. Chilliard. 2000. Effet de la nature de la ration de base et de la complémentation sur les performances de la chèvre laitière in 7 th Int. Conf. on Goats, Tours, France, 15-21 May 2000. Tome 1:142-144.

Rousselot, M. C., C. B. Broqua, C. de Araujo, and L. P. Borgida. 1995. Effets des fibres et des matières grasses protégées sur la composition du lait de chèvre. Ann. Zootech. 44(Suppl.):376.

Sauvant, D., Y. Chilliard, and P. Morand-Fehr. 1991. Etiological aspects of nutritional and metabolic disorders of goats in Goat Nutrition. P. Morand-Fehr, ed. Pudoc, Wageningen (NLD), EAAP Publ. No. 46:124-142.

Sauvant, D., P. M. Fehr, F. Rodolphe, R. Tomassone, and J. Delage. 1973. Etude des interrelations entre les critères de production et de composition lipidique du lait de chèvre par deux méthodes d'analyse factorielle. Ann. Biol. Anim. Biochim. Biophys. 13:107-129.

Sauvant, D., and P. Morand-Fehr. 2000. Quantitative analysis of dairy goat response to concentrate supply in 7th Int. Conf. on Goats, 15-21 May 2000, Tours, France. Tome 1:80-81.

Sauvant, D., P. Morand-Fehr, and P. Bas. 1983. L'intért des lipides dans les aliments concentrés. Pages K1-K17 in CAAA: Quels aliments concentrés pour les hautes productrices de lait. ADEPRINA, Paris, France.

Schmidely, P., and D. Sauvant. 2001. Taux butyreux et composition de la matière grasse du lait chez les petits ruminants: effets de l'apport de matières grasses ou d'aliment concentré. INRA Prod. Anim. 14:337-354.
Sébédio, J. L., S. Gnaedig, and J. M. Chardigny. 1999. Recent advances in conjugated linoleic acid research. Curr. Opin. Clin. Nutr. Metabolic Care 2:499-506.

Selner, D. R., and L. H. Schultz. 1980. Effects of feeding oleic acid or hydrogenated vegetable oils to lactating cows. J. Dairy Sci. 63:1235-1241.

Skjevdal, T. 1979. Flavor of goat's milk: A review of studies on the sources of its variations. Livest. Prod. Sci. 6:397-405.

Sleiman, F. T., M. I. Bayoun, M. G. Uwayjan, M. T. Farran, I. G. Rubeiz, R. F. Khalil, and V. M. Ashkarian. 1998. Influence of feeding calcium protected fat on goats milk production and composition. J. Anim. Sci. 76(Suppl. 1):302. (Abstr.)

Storry, J. E., and J. A. F. Rook. 1965. The effects of a diet low in hay and high in flaked maize on milk fat secretion and on the concentrations of certain constituents in the blood plasma of the cow. Br. J. Nutr. 19:101-109.

Sugiyama, T., H. Matsuura, H. Sasada, J. Masaki, and K. Yamashita. 1986. Characterization of fatty acids in the sebum of goats according to sex and age. Agric. Biol. Chem. 50:3049-3052.

Teh, T. H., L. T. Trung, Z. H. Jia, T. A. Gipson, K. B. Ogden, and T. F. Sweeney. 1994. Varying amounts of rumen-inert fat for high producing goats in early lactation. J. Dairy Sci. 77:253-258.

Ulbricht, T. L. V., and D. A. T. Southgate. 1991. Coronary heart disease: Seven dietary factors. Lancet 338:985-992.

Vegarud, G. E., T. G. Devold, R. Opheim, E. Loeding, C. Svenning, R. K. Abrahamsen, S. Lien, and T. Langsrud. 1999. Genetic variants of Norwegian goats milk composition, micellar size and renneting properties. Int. Dairy J. 9:367-368.

Williams, C. M. 2000. Dietary fatty acids and human health. Ann. Zootech. 49:165-180.

Wong, E., C. B. Johson, and L. N. Nixon. 1975. The contribution of 4-methyloctanoic (hircinoic) acid to mutton and goat meat flavor. N.Z. J. Agric. Res. 18:261-266. 